Keywords: ${ }^{129}$ I, radioiodine, sorption, natural organic carbon, $K_{d}$ value, distribution coefficient, performance assessment, oxidation state, redox, anaerobic, aerobic

Retention: Permanent

\title{
Radioiodine Geochemistry in the SRS Subsurface Environment
}

D. I. Kaplan, H. P. Emerson, ${ }^{a}$ B. A. Powell, ${ }^{\mathrm{a}}$ K. A. Roberts, S. Zhang, ${ }^{\mathrm{b}}$ C. Xu, ${ }^{b}$ K. A. Schwehr, ${ }^{b}$ H. P. Li, ${ }^{b}$ Y. F. Ho, ${ }^{b}$ M. E. Denham, C. Yeager, ${ }^{c}$ and P. H. Santschi ${ }^{\text {b }}$

${ }^{a}$ Clemson University

${ }^{\mathrm{b}}$ Texas A \& M University

${ }^{c}$ Los Alamos National Laboratory

May 2013

Savannah River National Laboratory Savannah River Nuclear Solutions, LLC Aiken, SC 29808

Prepared for the U.S. Department of Energy under contract number DE-AC09-08SR22470. 
SRNL-STI- 2012-00518

Revision 0

\section{DISCLAIMER}

This work was prepared under an agreement with and funded by the U.S. Government. Neither the U.S. Government or its employees, nor any of its contractors, subcontractors or their employees, makes any express or implied:

1. warranty or assumes any legal liability for the accuracy, completeness, or for the use or results of such use of any information, product, or process disclosed; or

2. representation that such use or results of such use would not infringe privately owned rights; or

3. endorsement or recommendation of any specifically identified commercial product, process, or service.

Any views and opinions of authors expressed in this work do not necessarily state or reflect those of the United States Government, or its contractors, or subcontractors.

\section{Printed in the United States of America}

Prepared for

U.S. Department of Energy 
SRNL-STI- 2012-00518

Revision 0

\section{REVIEWS AND APPROVALS}

\section{AUTHORS:}

\begin{tabular}{ll}
\hline D. I. Kaplan, Environmental Sciences, SRNL Date & DR
\end{tabular}

\begin{tabular}{ll}
\hline K. A. Roberts, Radiological Performance Assessment, SRNL Date
\end{tabular}

\begin{tabular}{lc}
\hline H. P. Emerson, Clemson University & Date
\end{tabular}

\begin{tabular}{lc}
\hline B. A. Powell, Clemson University & Date
\end{tabular}

\begin{tabular}{ll}
\hline S. Zhang, Texas A\&M Galveston Date & Dan
\end{tabular}

\begin{tabular}{lc}
\hline C. Xu, Texas A\&M Galveston & Date
\end{tabular}

\begin{tabular}{ll}
\hline K. A. Schwehr, Texas A\&M Galveston & Date
\end{tabular}

H. P. Li, Texas A\&M Galveston $\quad$ Date

\begin{tabular}{lc}
\hline Y. F. Ho, Texas A\&M Galveston & Date
\end{tabular}

\begin{tabular}{ll}
\hline P. H. Santschi, Texas A\&M Galveston Date & Dan
\end{tabular}

TECHNICAL REVIEW:

M. Whiteside, Environmental Sciences, SRNL Date

APPROVAL:

\begin{tabular}{lc}
\hline John J. Mayer, Environmental Sciences, SRNL Date & D
\end{tabular}

\begin{tabular}{lc}
\hline Alice Murray, Science and Technology, SRNL Date & D
\end{tabular} 


\section{EXECUTIVE SUMMARY}

Iodine-129 is one of the key risk drivers for several Savannah River Site (SRS) performance assessments (PA), including that for the Low-Level Waste Disposal Facility in E-Area. In an effort to reduce the uncertainty associated with the conceptual model and the input values used in PA, several studies have recently been conducted dealing with radioiodine geochemistry at the SRS. The objective of this report was to review these recent studies and evaluate their implications on SRS PA calculations. For the first time, these studies measured iodine speciation in SRS groundwater and provided technical justification for assuming the presence of more strongly sorbing species (iodate and organo-iodine), and measured greater iodine sediment sorption when experiments included these newly identified species; specifically they measured greater sorption coefficients $\left(\mathrm{K}_{\mathrm{d}}\right.$ values: the concentration ratio of iodine on the solid phase divided by the concentration in the aqueous phase).

Based on these recent studies, new best estimates were proposed for future PA calculations. The new $\mathrm{K}_{\mathrm{d}}$ values are greater than previous recommended values.

Present and proposed best-estimate sediment iodine $K_{d}$ values for SRS PA calculations.

\begin{tabular}{lcc}
\hline Subsurface sediment & $\begin{array}{c}\text { Present } \mathbf{K}_{\mathbf{d}} \\
(\mathbf{m L} / \mathbf{g})\end{array}$ & $\begin{array}{c}\text { Proposed new } \mathbf{K}_{\mathbf{d}} \\
\text { values }(\mathbf{m L} / \mathbf{g})\end{array}$ \\
\hline Sandy & 0.3 & 1 \\
Clayey & 0.9 & 3 \\
\hline
\end{tabular}

These proposed $\mathrm{K}_{\mathrm{d}}$ values reflect a better understanding of iodine geochemistry in the SRS subsurface environment, which permits reducing the associated conservatism included in the original estimates to account for uncertainty. Among the key contributing discoveries supporting the contention that the $\mathrm{K}_{\mathrm{d}}$ values should be increased are that: 1) not only iodide ( $\left.\mathrm{I}^{-}\right)$, but also the more strongly sorbing iodate $\left(\mathrm{IO}_{3}^{-}\right)$ species exists in SRS groundwater (average total iodine $=15 \%$ iodide, $42 \%$ iodate, and $43 \%$ organoiodine), 2) when iodine was added as iodate, the measured $K_{d}$ values were 2 to 6 times greater than when the iodine was added as iodide, and perhaps most importantly, 3) higher desorption (10 to $20 \mathrm{~mL} / \mathrm{g})$ than (ad)sorption (all previous studies) $\mathrm{K}_{\mathrm{d}}$ values were measured. The implications of this latter point is that the iodine desorption process would be appreciably slower than the (ad)sorption process, and as such would control the rate (and the PA $\mathrm{K}_{d}$ value) that iodine sorbed to and therefore migrated through the subsurface sediment. High desorption $\mathrm{K}_{d}$ values would result in the "effective $\mathrm{K}_{d}$ " for a reactive transport model being closer to the desorption $\mathrm{K}_{\mathrm{d}}$ value (the rate limiting value) than the (ad)sorption $\mathrm{K}_{\mathrm{d}}$ value. In summary, our understanding of ${ }^{129} \mathrm{I}$ geochemistry has greatly improved, reducing the uncertainty associated with the PA's conceptual model, thereby permitting us to reduce the conservatism presently incorporated in PA input values to describe ${ }^{129}$ I fate and transport in the SRS subsurface environment. 


\section{TABLE OF CONTENTS}

LIST OF TABLES. vi

LIST OF FIGURES vii

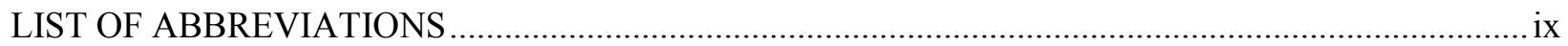

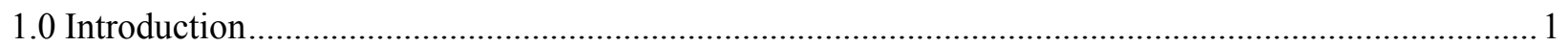

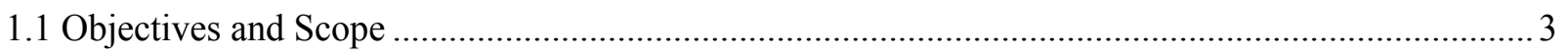

2.0 Iodine Speciation and Transformation in SRS Groundwater........................................................ 3

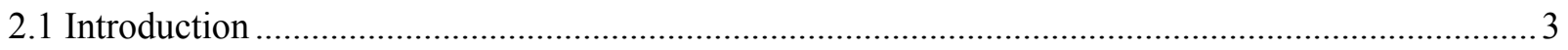

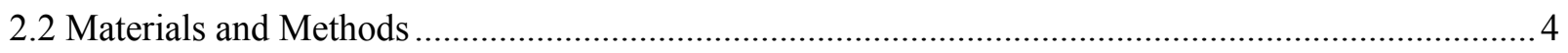

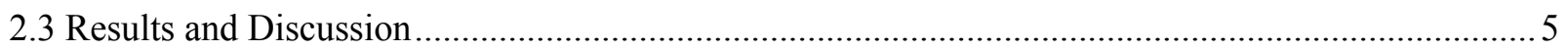

2.4 Implications of these results on SRS performance assessments................................................. 9

3.0 Speciation Transformations of Iodine in Contact with SRS Subsurface Sediments............................. 9

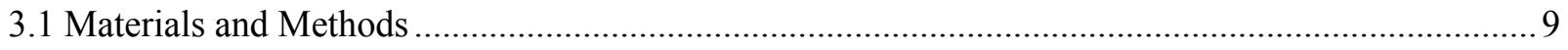

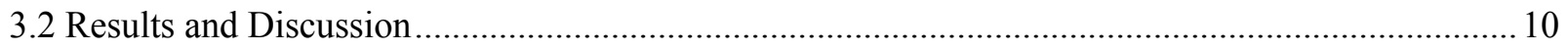

3.3 Implications of these results for SRS performance assessments ................................................ 14

4.0 Iodine $\mathrm{K}_{\mathrm{d}}$ Values as a Function of $\mathrm{pH}$, Reducing or Oxidizing Conditions, and Iodide or Iodate

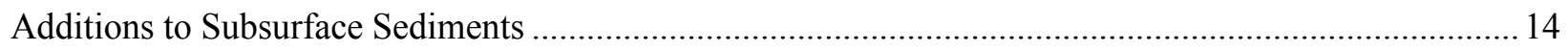

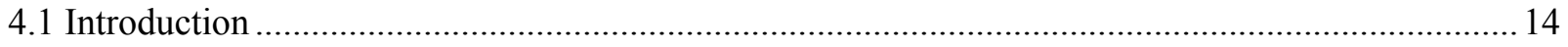

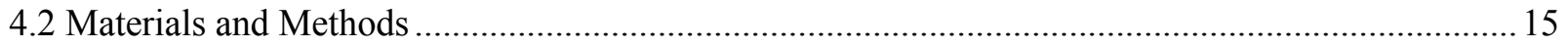

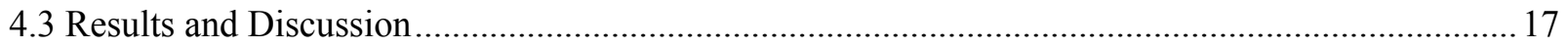

4.3.1 Iodine Added as Iodate $\left(\mathrm{I}_{\text {iodate }}\right)$ Sorption to Clayey Sediments under Aerobic Conditions ......... 17

4.3.2 Iodine Added as Iodide $\left(\mathrm{I}_{\text {iodide }}\right)$ Sorption to Clayey Sediments under Aerobic Conditions ......... 18

4.3.3 Influence of Concentration Dependent Studies ...................................................................... 21

4.3.4 Influence of Reducing and Oxidizing Conditions on Iodine Sorption to Iodide and Iodate

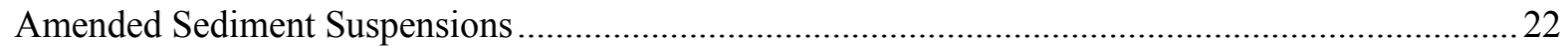

4.4 Implications of these results for SRS performance assessments ...............................................29

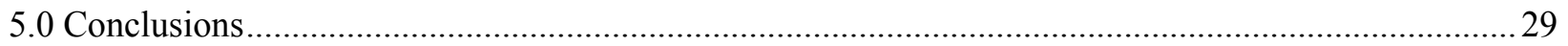

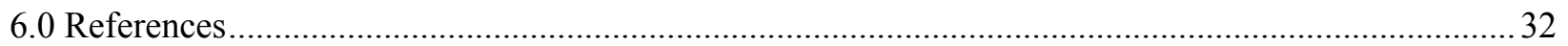

Appendix A: Additional Iodine $\mathrm{K}_{\mathrm{d}}$ Values for Wetland Sediments (Emerson et al. 2012) ...................... 35 
SRNL-STI- 2012-00518

Revision 0

\section{LIST OF TABLES}

Table 1. Hydrographical and chemical properties of SRS F-area groundwater. 7

Table 2. Concentrations of stable ${ }^{127}$ I and radioactive ${ }^{129}$ I species in groundwater collected from SRS's Farea. .

Table 3. Characterization of sediment used by Xu et al. (2011). 10

Table 4. Iodine (ad)sorption $\mathrm{K}_{\mathrm{d}}$ values (Equation 1) and desorption $\mathrm{K}_{\mathrm{d} \text {-desorp }}$ values (calculated as ratios of total iodine in $0.1 \mathrm{~N} \mathrm{KCl}$ extraction solution at equilibrium) at two concentrations (20 $\mu \mathrm{M}$ and 0.1 $\mu \mathrm{M}$ ) for the FSI-18 (organic-rich) and North Borrow (organic-poor) sediments, during a four-day contact experiment (values represent averages of duplicates and standard deviation were $<10 \%$ ) $\ldots 12$

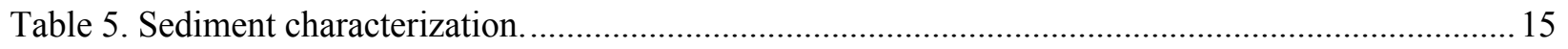

Table 7. $\mathrm{E}_{\mathrm{h}}$ measurements for sediments under aerobic conditions................................................... 23

Table 8. $\mathrm{E}_{\mathrm{h}}$ measurements for sediments under anaerobic conditions................................................ 24

Table 9. Iodine added as iodide $\left(\mathrm{I}_{\text {iodide }}\right) \mathrm{K}_{\mathrm{d}}$ values of sediments in oxidizing and reducing conditions after 8 days of equilibration. $K_{d}$ values corrected for natural iodine desorbed from sediments (uncorrected

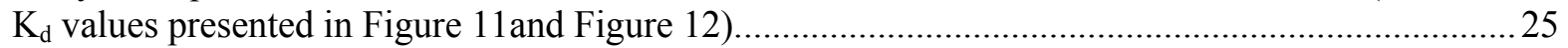

Table 10. Aqueous fraction $\left(\mathrm{I}_{\mathrm{aq}} / \mathrm{I}_{\text {total }}\right)$ of iodine (added as iodate) for sediments under oxidizing conditions.

Table 11. Aqueous fraction $\left(\mathrm{I}_{\mathrm{aq}} / \mathrm{I}_{\text {total }}\right)$ of iodine (added as iodate) for sediments under reducing conditions.

Table 12. Iodine added as iodate $\left(\mathrm{I}_{\text {iodate }}\right) \mathrm{K}_{\mathrm{d}}$ values of sediments in oxidizing and reducing conditions after 8 days of equilibration (data used here is presented in more detail in Figure 13 and Figure 14)....... 29

Table 13. Percent iodine species in groundwater that was minimally impacted by the presence of the FArea plume (Table 2).

Table 13. Previous (Kaplan 2009) and proposed best-estimate sediment iodine $\mathrm{K}_{\mathrm{d}}$ values for SRS PA calculations. 


\section{LIST OF FIGURES}

Figure 1. Relationships between $\mathrm{pH}$ and oxidation-reduction potential (ORP) in the SRS F-area groundwater (closed symbols) and from the upper aquifer in the SRS E-area, adjacent to the F-area. The inscribed area was adopted from (Baas-Becking et al., 1960) and is representative of most sediments. Lines representing $\mathrm{O}_{2} / \mathrm{H}_{2} \mathrm{O}$ and the $\mathrm{H}_{2} / \mathrm{H}_{2} \mathrm{O}$ couples provide limits of oxidation-reduction potentials in aqueous systems (organo-iodine was not considered in these calculations).................... 2

Figure 2. Map of F-Area field site showing seepage basins, sampling wells, remediation barrier, remediation base injection gate, groundwater flow direction, and Fourmile Branch wetland delineation (Otosaka et al., 2011).

Figure 3. For the iodide-amended North Borrow suspensions: (A) percent aqueous iodide in the $<3 \mathrm{kDa}$ fraction, $>3 \mathrm{kDa}$ fraction, and associated with the sediment; and (B) percent aqueous iodide, iodate, and organo-iodine (OI). For the iodate-amended North Borrow suspensions: (C) percent aqueous iodide in the $<3 \mathrm{kDa}$ fraction, $>3 \mathrm{kDa}$ fraction, and associated with the sediment; and (D) percent aqueous iodide, iodate, and organo-iodine (OI). 13

Figure 4. Iodine size fractionation after contact with the North Borrow sediment for four days when amended with (A) iodide or (B) iodate. 14

Figure 5. Iodine added as iodate $\mathrm{K}_{\mathrm{d}}$ values (Equation 1) to clayey sediment suspensions under variable $\mathrm{pH}$ aerobic conditions (1000 ppb total iodine, $25 \mathrm{~g} / \mathrm{L}$ sediment in $0.01 \mathrm{M} \mathrm{NaCl}$ ).

Figure 6. Iodine added as iodate $\mathrm{K}_{\mathrm{d}}$ values to clayey sediment suspensions in aerobic conditions with variable total iodine concentrations and contact times $(\mathrm{pH} \sim 4.7,25 \mathrm{~g} / \mathrm{L}$ sediment in $0.01 \mathrm{M} \mathrm{NaCl}) . .18$

Figure 7. Iodine added as iodide $\left(\mathrm{I}_{\text {iodide }}\right) \mathrm{K}_{\mathrm{d}}$ values in clayey sediment suspensions under variable-pH, aerobic conditions (1000 ppb total iodine, $25 \mathrm{~g} / \mathrm{L}$ sediment in $0.01 \mathrm{M} \mathrm{NaCl}$ ) (values not corrected for natural iodine desorption from sediment slightly increasing reported $\mathrm{K}_{\mathrm{d}}$ ).

Figure 8. Comparison of iodine sorption in $\mathrm{IO}_{3}{ }^{-}$and $\mathrm{I}^{-}$amended clayey sediment suspensions under aerobic and variable $\mathrm{pH}$ conditions after 8 and 12 weeks of equilibration $\left(1000 \mathrm{ppb} \mathrm{I}_{\text {total }}, 25 \mathrm{~g} / \mathrm{L}\right.$ sediment in $0.01 \mathrm{M} \mathrm{NaCl}$ ) (values not corrected for natural iodine desorption from sediment slightly increasing reported $\mathrm{K}_{\mathrm{d}}$ ).

Figure 9. Iodine added as iodide $\left(\mathrm{I}_{\text {iodide }}\right)$ to clayey sediment suspensions in aerobic conditions with variable total iodine concentrations ( $\mathrm{pH} \sim 4.7,25 \mathrm{~g} / \mathrm{L}$ sediment in $0.01 \mathrm{M} \mathrm{NaCl}$ ).

Figure 10. Iodine added as iodide and iodate sorption to a clayey and wetland sediment after seven days

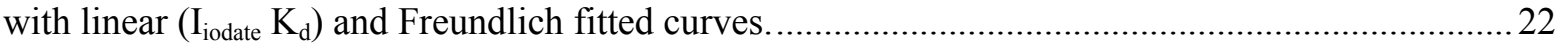

Figure 11. Iodine added as iodide $\mathrm{K}_{\mathrm{d}}$ values after 1 , 4, and 8 days for sediments under oxidizing conditions. Error bars represent average and standard deviation of $\mathrm{K}_{\mathrm{d}}$ values of five or six samples with varying initial concentrations.

Figure 12. Iodine added as iodide $\mathrm{K}_{\mathrm{d}}$ values of sediments under reducing conditions after 1 , 4, and 8 day equilibration times. Average and standard deviation of $I_{\text {iodide }} K_{d}$ values of 9 samples with varying amendment concentrations (except for the 1 and 4 day clayey, and 1 day wetland where $n=8$ samples, 1 day clayey where $n=7$ samples, and 4 and 8 day sandy, and 4 day wetland where $n=6$ samples). 
Figure 15. Iodine added as iodide $\left(\mathrm{I}_{\text {iodide }}\right)$ sorption wetland sediment suspensions as a function of $\mathrm{pH}(25$ $\mathrm{g} / \mathrm{L}$ sediment; $\mathrm{I}_{\text {total }}=1000 \mathrm{ppb}$, and $0.01 \mathrm{M} \mathrm{NaCl}$ under aerobic conditions)......

Figure 16. Iodine added as iodate $\left(\mathrm{I}_{\text {iodate }}\right)$ sorption to wetland sediment suspensions as a function of $\mathrm{pH}$ (25 g/L sediment; $\mathrm{I}_{\text {tota }}=1000 \mathrm{ppb}$; and $0.01 \mathrm{M} \mathrm{NaCl}$ under aerobic conditions)....... 37 


\section{LIST OF ABBREVIATIONS}

\begin{tabular}{|c|c|}
\hline $\mathrm{AEC}$ & Anion exchange capacity \\
\hline BDL & Below detection limits \\
\hline BET & Brunaer, Emmet and Taller surface area \\
\hline CEC & Cation exchange capacity \\
\hline DOC & Dissolved organic carbon \\
\hline DOE & Department of Energy \\
\hline GC-MS & Gas chromatography - mass spectroscopy \\
\hline $\mathrm{I}_{\text {iodate }}$ & Iodine added as iodate \\
\hline $\mathrm{I}_{\text {iodide }}$ & Iodine added as iodide \\
\hline $\mathrm{I}^{-}$ & Iodide \\
\hline $\mathrm{IO}_{3}^{-}$ & Iodate \\
\hline CP-MS & Inductive couple plasma - mass spectroscopy \\
\hline $\mathrm{K}_{\mathrm{d}}$ & Distribution coefficient \\
\hline $\mathrm{K}_{\mathrm{d} \text {-desorp }}$ & Distribution coefficient measured by desorption \\
\hline MCL & Maximum contaminant level \\
\hline ORP & Oxidation-reduction potential \\
\hline $\mathrm{SOM}$ & Sediment organic matter \\
\hline $\mathrm{OC}$ & Organic carbon \\
\hline $\mathrm{OM}$ & Organic Matter \\
\hline ORP & Oxygen reduction potential \\
\hline PA & Performance assessment \\
\hline SRNL & Savannah River National Laboratory \\
\hline SRS & Savannah River Site \\
\hline
\end{tabular}




\subsection{Introduction}

The geochemical behavior of iodine is complex because it can exist in multiple physical states, as well as multiple oxidation states at environmentally relevant conditions. It readily reacts with organic compounds, further complicating its chemistry in organic-rich environments. Iodine is also an essential nutrient for animals that concentrates in the thyroid gland, greatly enhancing its toxicity. This tendency for high bioaccumulation, together with its long half-life and relatively high mobility in the environment, commonly results in ${ }^{129} \mathrm{I}$ becoming a key risk driver at sites where radioactive waste is disposed, including the Hanford Site, Savannah River Site, Nevada Test Site, and high-level waste repository (e.g., (DOE, 2002, 2003, 2012; WSRC, 2008). To illustrate how the properties of ${ }^{129}$ I magnify its risk, ${ }^{129}$ I accounts for only $0.00002 \%$ of the radiation released offsite from the SRS, but contributes $13 \%$ of the population dose, a six order-of-magnitude magnification of risk with respect to its radioactivity (Kantelo et al., 1990).

Iodine in aquatic systems can be grouped into three species; iodide $\left(\mathrm{I}^{-}\right)$, iodate $\left(\mathrm{IO}_{3}{ }^{-}\right)$and organoiodine (org-I). Because the speciation of iodine is affected by various parameters of water chemistry, such as temperature, $\mathrm{pH}$, oxidation-redox potential, and organic carbon concentrations, it is necessary to understand the cause of speciation to better predict the behavior of ${ }^{129} \mathrm{I}$ in the environment. With regard to inorganic iodine (iodide and iodate), based on thermodynamic considerations, iodine exists almost exclusively as iodide in groundwater and anoxic surface waters (Figure 1). Recent studies with SRS and Hanford groundwater, however, reported that a significant proportion of ${ }^{129} \mathrm{I}$ existed as iodate (Kaplan et al., 2012; Otosaka et al., 2011; Santschi et al., 2012; Schwehr et al., 2009; Zhang et al., 2010a). The processes that produce ${ }^{129}$ I-iodate under these conditions have not been identified.

In the last five years there have been major findings related to ${ }^{129} \mathrm{I}$ geochemistry that have implications to the sediment ${ }^{129} \mathrm{I} \mathrm{K}_{\mathrm{d}}$ values used in SRS performance assessments (PAs). ${ }^{129} \mathrm{I} \mathrm{K}_{\mathrm{d}}$ values used in these calculations may have been under estimated in the past for various reasons.

1. Iodine speciation: Up until recently, it has been assumed that the major iodine species in groundwater aquifers is iodide $\left(\mathrm{K}_{\mathrm{d}}=0\right.$ to $\left.1 \mathrm{~mL} / \mathrm{g}\right)$. However, recent work at the SRS has demonstrated that other stronger sorbing species of iodine also exist under ambient conditions in the groundwater, including iodate $\left(\mathrm{K}_{\mathrm{d}}=\sim 10 \mathrm{~mL} / \mathrm{g}\right)$ and organo-iodine species $\left(\mathrm{K}_{\mathrm{d}}=1000 \mathrm{~mL} / \mathrm{g}\right)$ (Otosaka et al., 2011; Xu et al., 2011a; Xu et al., 2012; Zhang et al., 2010a). The presence of these other species within the iodine pool of species significantly increases the potential to interact with the SRS sediment. All previous laboratory ${ }^{129} \mathrm{I} \mathrm{K}_{\mathrm{d}}$ measurements have spiked iodide into SRS sediment suspensions.

2. Natural organic matter $-{ }^{129} \mathbf{I}$ strong bond: Groundwater iodine forms covalent bonds (near irreversible bonds) with sediment organic matter; few radionuclides form such bonds with sediment particles (Xu et al., 2011a; Xu et al., 2011b; Xu et al., 2012; Zhang et al., 2011). The clay fraction of the SRS subsurface environment commonly has between 300 and 700 ppm organic carbon, which is about eight orders-of-magnitude greater than ${ }^{129} \mathrm{I}$ concentrations commonly measured in SRS plumes $\left(60 \mathrm{pCi} / \mathrm{L}^{129} \mathrm{I}\right.$; Maximum Concentration Limit $\left.(\mathrm{MCL})=1 \mathrm{pCi} / \mathrm{L}=6 \times 10^{-6} \mathrm{ppm}\right)$. Therefore, portions of the organic matter present in the sediment, placed there during the geological formation of the aquifer, may be sufficient to irreversibly bind the ${ }^{129} \mathrm{I}$. This organic matter may provide some natural attenuation that is presently not being accounted for in SRS geochemical models.

3. Improved analytical capabilities leading to new understanding of ${ }^{129} I$ biogeochemistry: A new analytical method has been developed which permits measurement of aqueous iodine species, ${ }^{129} \mathrm{I}$ and stable ${ }^{127}$ I, at ambient concentrations (Schwehr and Santschi, 2003; Zhang et al., 2010a). What is 
important to SRS about this method is that it permits researchers to work at performance assessment appropriate concentrations, about 1 to $50 \mathrm{pCi} / \mathrm{L}$, and to measure $\mathrm{K}_{\mathrm{d}}$ values with the correct (SRS specific) ${ }^{129} \mathrm{I}$ species. Otherwise, by using elevated ${ }^{129} \mathrm{I}$ concentrations, researchers may underestimate the true iodine $K_{d}$ values and compromise technical defensibility.

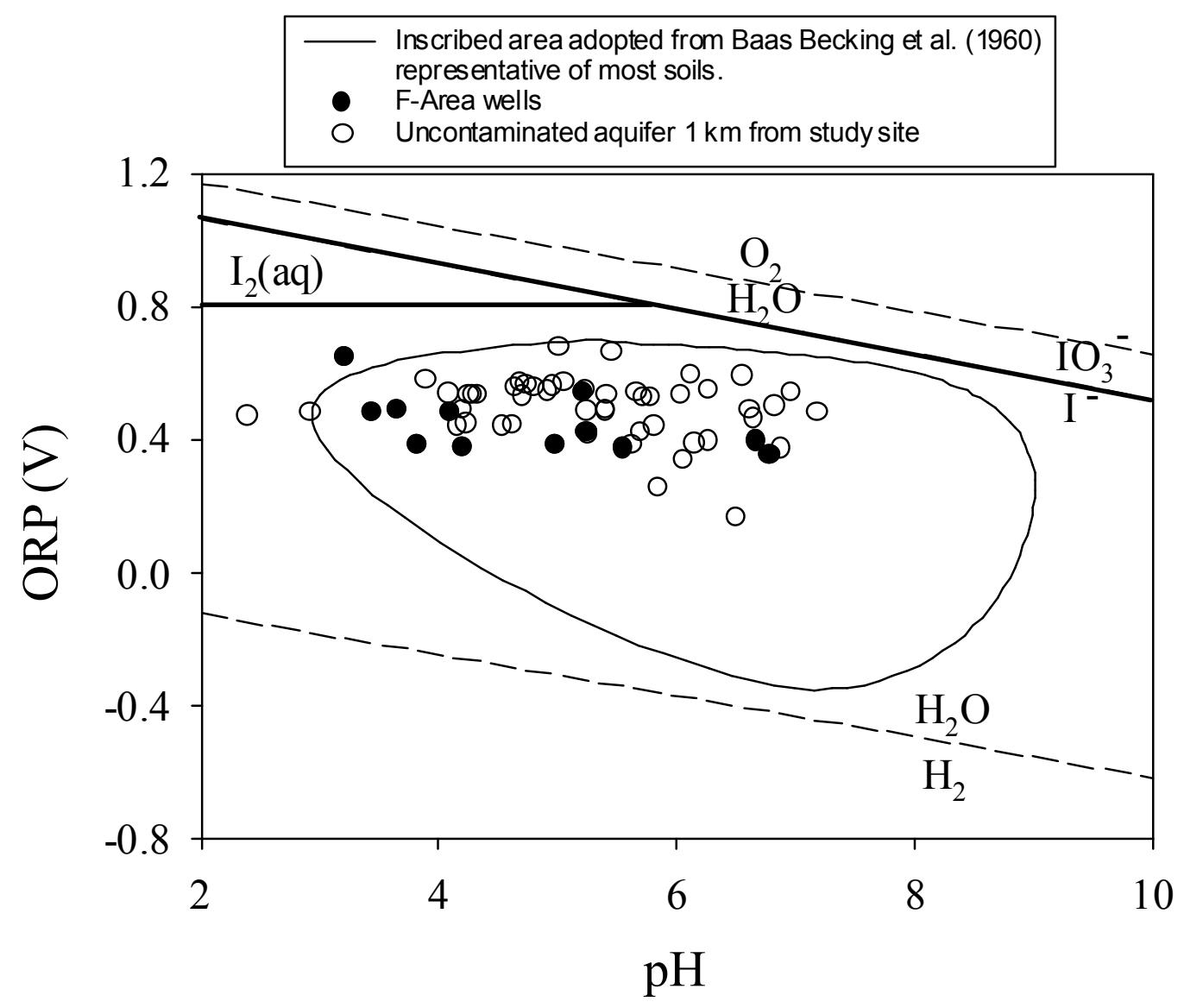

Figure 1. Relationships between $\mathrm{pH}$ and oxidation-reduction potential (ORP) in the SRS F-area groundwater (closed symbols) and from the upper aquifer in the SRS E-area, adjacent to the Farea. The inscribed area was adopted from (Baas-Becking et al., 1960) and is representative of most sediments. Lines representing $\mathrm{O}_{2} / \mathrm{H}_{2} \mathrm{O}$ and the $\mathrm{H}_{2} / \mathrm{H}_{2} \mathrm{O}$ couples provide limits of oxidationreduction potentials in aqueous systems (organo-iodine was not considered in these calculations). 


\subsection{Objectives and Scope}

The objective of this report is to critically review recent field and laboratory ${ }^{129}$ I geochemical research and evaluate their implications on SRS performance assessments. The implications of three recent studies using SRS groundwater and sediment will be reviewed (Emerson and Powell, 2012; Lilley et al., 2010; Otosaka et al., 2011; Xu et al., 2011a). The scope of this report was limited to whether the relatively low concentrations of organic carbon in the SRS subsurface sediment (200 to $600 \mathrm{ppm} \mathrm{C}$ ) influence ${ }^{129} \mathrm{I}$ geochemistry. Consequently, the large amount of recent research attempting to explain why ${ }^{129} \mathrm{I}$ concentrates in the F-Area wetland environment, a high organic carbon environment, will not be discussed in this document. Similarly, projects designed to explain the nature of the iodine-natural organic carbon bond will also not be discussed. Though both of these aspects of iodine geochemistry are important to the PA, understanding of these processes does not directly impact the numerical modeling of

${ }^{129}$ I under most PA conditions. For this review, attention was directed at iodine sorption studies with loworganic carbon subsurface sediments with the intent to evaluate the existing ${ }^{129} \mathrm{I} \mathrm{K}_{\mathrm{d}}$ values used in SRS PAs (Kaplan, 2009):

- Subsurface sandy sediment iodine $\mathrm{K}_{\mathrm{d}}=0.3 \mathrm{~mL} / \mathrm{g}$, and

- $\quad$ Subsurface clayey sediment iodine $\mathrm{K}_{\mathrm{d}}=0.9 \mathrm{~mL} / \mathrm{g}$.

The report is organized to discuss the present knowledge of iodine speciation and transformations in SRS groundwater (Section 2.0). The following section (Section 3.0) demonstrates how subsurface sediments promote iodine speciation changes as a function of time; addressing questions such as, "If iodide is released from its buried waste form, how long will it remain as iodide before it converts to the stronger sorbing species iodate or organo iodide?" Then the change in iodine $\mathrm{K}_{\mathrm{d}}$ values as a function of whether iodide or iodate is added, $\mathrm{pH}$ values, and oxidizing and reducing conditions are discussed (Section 4.0).

\subsection{Iodine Speciation and Transformation in SRS Groundwater}

\subsection{Introduction}

As discussed in relation to Figure 1, iodine speciation in the SRS subsurface has always been assumed to be iodide. The implications of this assumption are that iodide, a very weakly sorbing species was used as the initial starting material in the batch sorption measurements, i.e., in the $\mathrm{K}_{\mathrm{d}}$ value measurements (Kaplan, 2002, 2006; Stone et al., 1985). Such a conservative assumption may result in underestimating the true ${ }^{129}$ I sorption when iodate and organo-iodine are also present.

Understanding the nature of stable and radioactive iodine existing in SRS groundwater as opposed to that in simulated laboratory studies was expected to provide greater insight into how radioiodine would impact SRS PA results. There have been three recent studies conducted in ${ }^{129}$ I-plumes in F-Area to identify the speciation of ${ }^{129}$ I under natural SRS conditions (Kaplan et al., 2011; Otosaka et al., 2011; Schwehr et al., 2009). The most comprehensive SRS groundwater speciation description of ${ }^{129}$ I and stable ${ }^{127}$ I was presented by Otosaka et al. (2010), and is the primary subject of this section. The implications of these results on the SRS PA are discussed (Section 2.4). 


\subsection{Materials and Methods}

The largest and most concentrated ${ }^{129} \mathrm{I}$ plume at the SRS emanates from the F-Area Seepage Basins (Figure 2). Otosaka et al. (2011) measured radioactive ${ }^{129} \mathrm{I}$ and stable ${ }^{127} \mathrm{I}$ concentrations in several wells in and adjacent to this plume (Figure 2). The waste introduced in these seepage basins originate from plutonium separations. The $1.5-\mathrm{km}$ plume is highly acidic and flows along a transect from the seepage basins down to Four Mile Branch, $15 \mathrm{~km}$ upstream from the Savannah River (WSRC, 2006). Two curies of ${ }^{129}$ I were estimated to be disposed in these seepage basins during operations between 1955 and 1988 (Killian et al., 1985). Presently, there is a funnel-and-gate base injection remediation system at the site. This system includes a subsurface wall, extending about $600 \mathrm{~m}$ perpendicular to the plume, and two "gates," where base is injected into the aquifer (WSRC, 2006). Otosaka et al. (2011) included a total of 12 sampling wells: three wells adjacent to the plume, three wells in the plume and above the remediation wall, four wells in the plume and below the wall, and two wells in the plume and below the injection gates (i.e., wells that would be expected to be significantly influenced by the presence of the base from the remediation effort) (Figure 2 and Table 1) (Otosaka et al., 2011). During groundwater collection, ancillary groundwater analyses were conducted for temperature, $\mathrm{pH}, \mathrm{E}_{\mathrm{h}}$, and dissolved $\mathrm{O}_{2}$. The samples were returned to the laboratory and analyzed for dissolved carbon, tritium, and iodine speciation. Iodide, iodate, and organo-iodine concentrations were determined for stable iodine, ${ }^{127} \mathrm{I}$, and radioactive iodine, ${ }^{129} \mathrm{I}$, using a gas chromatograph - mass spectrometer method (GC-MS) involving iodide derivitization to 4-iodo- $N, N$-dimethylaniline (Zhang et al., 2010b). Additional information about sampling, laboratory procedures, and sample storage is presented in Otosaka et al. (2011). 
SRNL-STI- 2012-00518

Revision 0
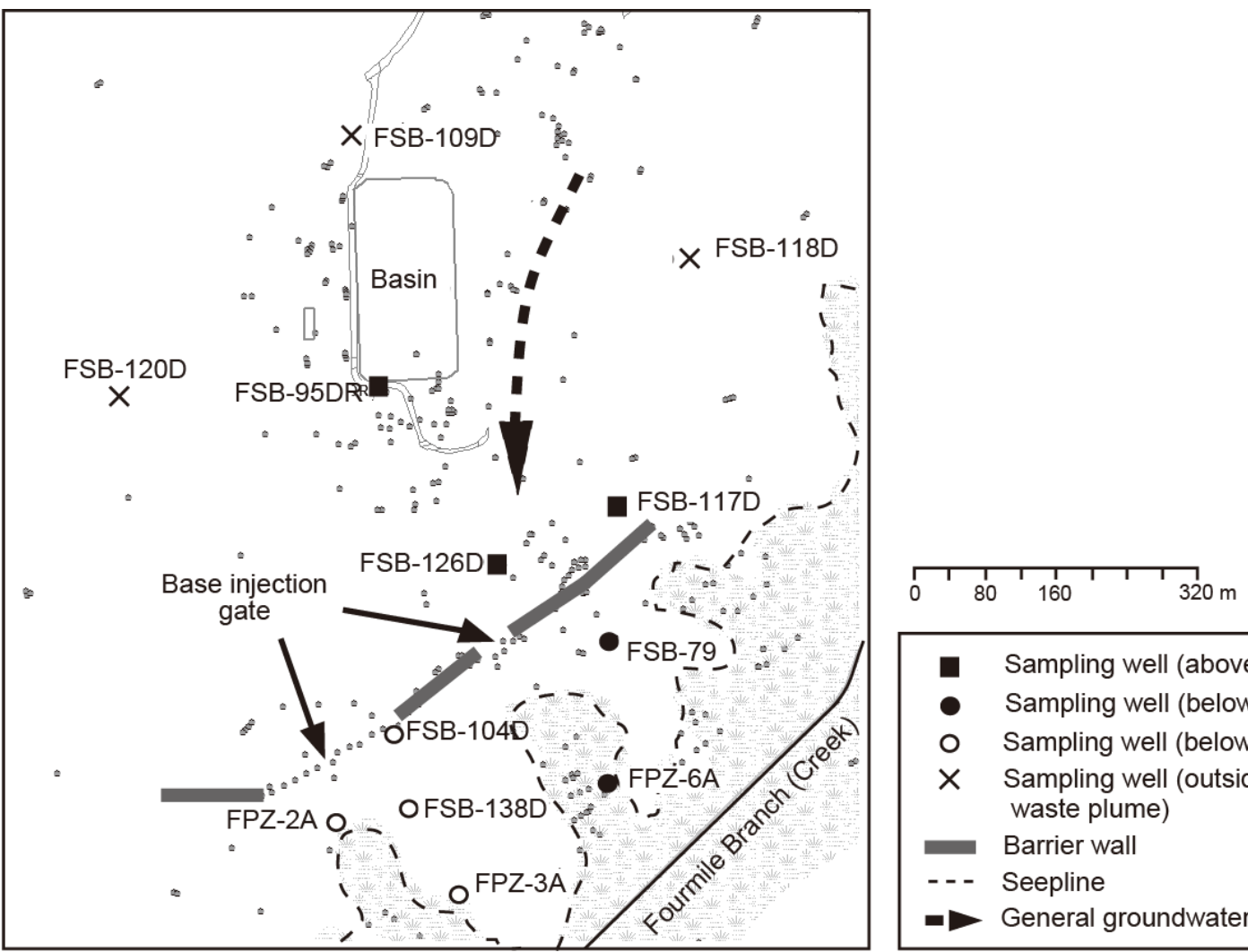

\begin{tabular}{|cl|}
\hline 口 & Sampling well (above barrier/gate) \\
O & Sampling well (below barrier) \\
$\times$ & Sampling well (below gate) \\
& Sampling well (outside the mixed \\
& Barrier wall \\
--- & Seepline \\
- & General groundwater flow
\end{tabular}

Figure 2. Map of F-Area field site showing seepage basins, sampling wells, remediation barrier, remediation base injection gate, groundwater flow direction, and Fourmile Branch wetland delineation (Otosaka et al., 2011).

\subsection{Results and Discussion}

Ancillary data associated with the groundwater characterization is presented in Table 1. The data is organized into four well-location categories: 1) above the remediation barrier, 2) below the barrier, 3) below the base injection gate (expected to be significantly influenced by the occasional base injection) and 4) outside of the ${ }^{129} \mathrm{I}$ plume. The $\mathrm{pH}$ outside of the plume averaged $\mathrm{pH} 5.2$, whereas the average $\mathrm{pH}$ inside the plume was closer to $\mathrm{pH} 3.8$ and the $\mathrm{pH}$ immediately downstream of the base injection gate was pH 5.4 (Table 1). The aquifer was generally oxidizing, as indicated by oxygen-reduction potential (ORP) measurements. Dissolved organic matter (DOC) concentrations generally decreased with distance from the seepage basin, suggesting some organic compound is being released from the seepage basin. Because the travel time for tritium between the seepage basins and Four Mile Branch is in the order of 13 years (WSRC, 2006), tritium reached Four Mile Branch decades ago, consequently, it is expected that the tritium data do not show any trend with distance from the seepage basins (Table 1).

Groundwater stable iodine, ${ }^{127} \mathrm{I}$, and radioiodine, ${ }^{129} \mathrm{I}$, speciation concentrations are presented in Table $2 .{ }^{127}$ I concentrations were not constant in the plume; instead they were highest near the seepage basin. Not unexpectedly, this concentration trend with distance from the seepage basin was also generally true of ${ }^{129}$ I. Generally all three iodine species were present in the groundwater. The only iodine speciation trends discernible from this data set were that there was generally: 1) more iodide near the basins (well FSB-95DR) than downstream of the basins and 2) more iodate in the groundwater influenced by the base 
injection (FSB-104D, FSB-138D, FPZ-2A) than not influenced by the base injection. These trends appear for both ${ }^{127} \mathrm{I}$ and especially for ${ }^{129} \mathrm{I}$. Simple correlations were conducted between the parameters in Table 1 and Table 2. Selected correlations include:

- $\quad{ }^{129} \mathrm{I}^{-}$and ${ }^{127} \mathrm{I}^{-}$concentrations were significantly $(\mathrm{p} \leq 0.01)$ correlated; $\mathrm{r}=0.975$,

- ${ }^{129} \mathrm{IO}_{3}{ }^{-}$and ${ }^{127} \mathrm{IO}_{3}{ }^{-}$concentrations were significantly $(\mathrm{p} \leq 0.01)$ correlated; $\mathrm{r}=0.703$,

- organo- ${ }^{129} \mathrm{I}$ and organo- ${ }^{127} \mathrm{I}$ concentrations were not correlated; $\mathrm{r}=-0.029$,

- $\quad{ }^{127} \mathrm{I}^{-}$concentrations were significantly $(\mathrm{p} \leq 0.01)$ inversely correlated to $\mathrm{pH} ; \mathrm{r}=-0.674$, and

- DOC was positively correlated to ${ }^{129} \mathrm{I}^{-}$and ${ }^{129} \mathrm{IO}_{3}{ }^{-}$concentrations; $\mathrm{r}=0.894$ and 0.957 , respectively. 
Table 1. Hydrographical and chemical properties of SRS F-area groundwater.

\begin{tabular}{|c|c|c|c|c|c|c|c|}
\hline Well & $\begin{array}{l}\text { Well-location } \\
\text { category }^{\mathrm{a}}\end{array}$ & $\begin{array}{l}\text { Distance from } \\
\text { seepage basin } \\
(\mathrm{m})\end{array}$ & $\begin{array}{l}\text { Temp } \\
\left({ }^{\circ} \mathrm{C}\right)\end{array}$ & $\mathrm{pH}$ & $\begin{array}{c}\text { ORP } \\
(\mathrm{SHE} ; \mathrm{mV})\end{array}$ & $\begin{array}{c}\text { Tritium } \\
\left(\mathrm{kBq} \mathrm{L}^{-1}\right)\end{array}$ & $\begin{array}{c}\mathrm{DOC} \\
\left(\mu \mathrm{mol} \mathrm{L}{ }^{-1}\right)\end{array}$ \\
\hline \multirow[t]{2}{*}{ FSB-95DR $^{c}$} & Above Barrier & 21 & $\mathrm{NA}^{\mathrm{b}}$ & NA & NA & NA & NA \\
\hline & Above Barrier & 21 & 21.9 & 3.20 & 654 & $23.3 \pm 2.4$ & $60.5 \pm 2.2$ \\
\hline FSB-126D & Above Barrier & 241 & 22.9 & 3.42 & 491 & $70.7 \pm 7.1$ & $29.9 \pm 1.3$ \\
\hline FSB-117D & Above Barrier & 269 & 20.7 & 3.60 & 494 & $27.1 \pm 2.7$ & $8.3 \pm 0.0$ \\
\hline FSB-79 & Below Barrier & 379 & 21.8 & 5.20 & 428 & $25.3 \pm 2.6$ & $16.2 \pm 0.4$ \\
\hline \multirow[t]{3}{*}{ FPZ-6A ${ }^{d}$} & Below Barrier & 532 & NA & NA & NA & NA & NA \\
\hline & Below Barrier & 532 & NA & NA & NA & NA & NA \\
\hline & Below Barrier & 532 & 18.0 & 3.81 & 391 & $95.1 \pm 9.5$ & $13.8 \pm 1.1$ \\
\hline FSB-104D & Below Base Injection & 432 & 22.0 & 6.66 & 402 & $0.12 \pm 0.03$ & $22.6 \pm 1.0$ \\
\hline FSB-138D & Below Base Injection & 521 & 20.9 & 4.18 & 384 & $8.47 \pm 0.87$ & $15.5 \pm 0.5$ \\
\hline FPZ-2A & Below Base Injection & 538 & 18.3 & 6.77 & 360 & $2.70 \pm 0.29$ & $5.5 \pm 0.3$ \\
\hline FPZ-3A & Below Base Injection & 630 & 19.5 & 4.08 & 487 & $5.29 \pm 0.55$ & $33.4 \pm 2.2$ \\
\hline FSB-109D & Outside of Plume & 60 & 23.8 & 5.53 & 381 & $1.99 \pm 0.22$ & $35.6 \pm 1.7$ \\
\hline FSB-118D & Outside of Plume & 290 & 19.2 & 4.97 & 392 & $0.40 \pm 0.06$ & $16.6 \pm 1.5$ \\
\hline FSB-120D & Outside of Plume & 303 & 21.7 & 5.20 & 550 & $1.41 \pm 0.16$ & $13.6 \pm 0.8$ \\
\hline
\end{tabular}

${ }^{\mathrm{a}}$ Well category: sampling wells are categorized into four regional groups: 1) above remediation barrier wall, 2) below remediation barrier wall, 3) below remediation base injection (greatly influenced by caustic subsurface base injection), and 4) outside of plume.

${ }^{\mathrm{b}} \mathrm{NA}=$ not available, measurements were not made.

${ }^{c}$ FSB-95DR was sampled on two dates: 6/1/2009 and 8/3/2010.

${ }^{\mathrm{d}}$ FPZ-6A was sampled on three dates: 1/6/2010, 2/8/2010, and 7/21/2010 
Table 2. Concentrations of stable ${ }^{127}$ I and radioactive ${ }^{129}$ I species in groundwater collected from SRS's F-area.

\begin{tabular}{|c|c|c|c|c|c|c|c|}
\hline \multirow{2}{*}{$\begin{array}{l}\text { Sampling } \\
\text { location }\end{array}$} & \multirow{2}{*}{$\begin{array}{l}\text { Sampling } \\
\text { date }\end{array}$} & \multicolumn{3}{|c|}{${ }^{127}$ I concentration $\left(\mathrm{nmol} \mathrm{L}{ }^{-1}\right)$} & \multicolumn{3}{|c|}{${ }^{129} \mathrm{I}$ concentration $\left(\mathrm{Bq} \mathrm{L}^{-1}\right)$} \\
\hline & & Iodide & Iodate & Organo I & Iodide & Iodate & Organo I \\
\hline \multirow[t]{2}{*}{ FSB-95DR } & $2009 / 8 / 1$ & $172 *$ & $0.0^{*}$ & $77.2 *$ & $5.65^{*}$ & $0.10^{*}$ & $0.83^{*}$ \\
\hline & $2010 / 8 / 3$ & $189 \pm 13^{a}$ & $70.2 \pm 24.6$ & $110 \pm 28$ & $5.81 \pm 0.68$ & $1.52 \pm 0.72$ & $3.23 \pm 0.82$ \\
\hline FSB-126D & $2010 / 8 / 3$ & $80.6 \pm 4.5$ & $12.0 \pm 10.4$ & $16.8 \pm 11.0$ & $1.15 \pm 0.18$ & $0.91 \pm 0.34$ & $\mathrm{BDL}^{\mathrm{b}}$ \\
\hline FSB-117D & $2010 / 7 / 12$ & $75.6 \pm 4.3$ & $60.6 \pm 16.0$ & $73.6 \pm 17.9$ & $1.29 \pm 0.45$ & $0.97 \pm 0.46$ & $2.52 \pm 0.74$ \\
\hline FSB-79 & 2010/7/9 & $56.1 \pm 1.9$ & $27.8 \pm 5.1$ & $56.1 \pm 23.0$ & $1.29 \pm 0.28$ & $-0.10 \pm 0.29$ & $0.59 \pm 0.30$ \\
\hline \multirow[t]{3}{*}{ FPZ-6A } & $2010 / 1 / 6$ & $55.3^{*}$ & $20.8^{*}$ & $32.6^{*}$ & $0.51 *$ & $1.17 *$ & $0.55^{*}$ \\
\hline & $2010 / 2 / 8$ & $95.7 *$ & $53.4 *$ & $46.8^{*}$ & $2.07 *$ & $1.33^{*}$ & $1.01 *$ \\
\hline & $2010 / 7 / 21$ & $72.9 \pm 4.2$ & $34.9 \pm 13.6$ & $32.4 \pm 14.8$ & $1.41 \pm 0.16$ & $1.09 \pm 0.30$ & $2.23 \pm 0.34$ \\
\hline FSB-104D & $2010 / 7 / 12$ & $13.6 \pm 1.6$ & $75.0 \pm 4.3$ & $48.8 \pm 6.5$ & $\mathrm{BDL}^{\mathrm{b}}$ & $0.73 \pm 0.18$ & $\mathrm{BDL}$ \\
\hline FSB-138D & $2010 / 8 / 24$ & $12.9 \pm 0.2$ & $35.1 \pm 3.0$ & $19.9 \pm 5.0$ & BDL & $0.34 \pm 0.10$ & $0.81 \pm 0.27$ \\
\hline FPZ-2A & $2010 / 7 / 21$ & $0.8 \pm 1.8$ & $11.0 \pm 2.3$ & $6.1 \pm 2.1$ & BDL & BDL & $\mathrm{BDL}$ \\
\hline FPZ-3A & $2010 / 7 / 21$ & $5.1 \pm 2.3$ & $7.5 \pm 2.5$ & $24.1 \pm 2.7$ & BDL & BDL & BDL \\
\hline FSB-109D & 2010/7/9 & $3.0 \pm 3.0$ & $4.6 \pm 3.2$ & $35.5 \pm 3.0$ & BDL & BDL & BDL \\
\hline FSB-118D & $2010 / 7 / 8$ & $3.7 \pm 1.7$ & $27.0 \pm 5.2$ & $2.7 \pm 5.4$ & $\mathrm{BDL}$ & BDL & BDL \\
\hline FSB-120D & $2010 / 7 / 13$ & $16.2 \pm 3.4$ & $21.7 \pm 10.0$ & $25.0 \pm 10.1$ & BDL & BDL & BDL \\
\hline $\begin{array}{l}\text { Four Mile } \\
\text { Branch }\end{array}$ & $2010 / 7 / 13$ & $39.4 \pm 3.5$ & $18.6 \pm 4.6$ & $82.6 \pm 7.9$ & $\mathrm{BDL}$ & BDL & BDL \\
\hline
\end{tabular}

* indicate data where $\mathrm{n}=1$ (no replicates).

a Errors indicate 1-sigma statistics of duplicate analysis.

${ }^{\mathrm{b}}$ BDL: Below detection limit 
SRNL-STI-2012-00518

Revision 0

\subsection{Implications of these results on SRS performance assessments}

The primary implications of these results on the SRS performance assessment are:

- Radioiodine will exist in the subsurface environment as multiple species. As will be discussed in Sections 3.0 and 4.0, each of these species sorb to SRS subsurface sediments to differing degrees, specifically iodate has a much greater $\mathrm{K}_{\mathrm{d}}$ value than iodide.

- $\mathrm{pH}$ likely influences the speciation of groundwater iodine; a greater iodate fraction exists in elevated $\mathrm{pH}$ systems $(\mathrm{pH}>6)$. This may be important in areas where cement leachate with elevated $\mathrm{pH}$ plumes exist. The opposing effect of higher salt concentrations in cement leachate may result in decreased iodine sorption.

- Previous experimental ${ }^{129} \mathrm{I} \mathrm{K}_{\mathrm{d}}$ values were measured by adding iodide. It is likely that once the iodide was added to the sediment suspensions in these experiments that a portion of it started to convert to iodate and organo-iodine. As such, these experiments did not measure the speciesspecific $\mathrm{K}_{\mathrm{d}}$ value of iodide, but more precisely, they measured a $\mathrm{K}_{\mathrm{s}}$ value of some combination of iodide/iodate/organo-iodine. This will be discussed in more detail in Section 3.0. If these systems did not reach steady state with respect to iodine speciation transformation, than the measured $\mathrm{K}_{\mathrm{d}}$ values were likely lower than may be expected under steady-state PA conditions. This would result in the previous PA using an overly conservative (low) ${ }^{129} \mathrm{I} \mathrm{K}_{d}$ value. Under field conditions, iodine speciation transformations and partitioning to the aquifer matrix likely achieve steady state relatively quickly with respect to SRS groundwater flow, therefore the use of $\mathrm{K}_{\mathrm{d}}$ values based on an equilibrated iodide/iodate/organo-iodine mixture is justified.

- The SRS subsurface environment promotes the transformation of ${ }^{129} \mathrm{I}$. It appears that ${ }^{129} \mathrm{I}$ was introduced into the seepage basins primarily as iodide, but as the ${ }^{129} \mathrm{I}^{-}$plume moved through the SRS aquifer, consisting of a $\mathrm{pH}$ and Eh gradient, the iodide underwent transformation to greater concentrations of iodate and organo-iodine.

\subsection{Speciation Transformations of Iodine in Contact with SRS Subsurface Sediments}

As noted in Section 2, groundwater radioiodine underwent speciation transformations in the SRS subsurface. The objective of the studies by Xu et al. (2011) was to conduct controlled experiments to quantify and determine the role that subsurface SRS sediments play in facilitating these transformations. Understanding and quantifying these transformations are important because iodine $\mathrm{K}_{\mathrm{d}}$ values will change with these transformations.

\subsection{Materials and Methods}

Laboratory batch sorption experiments were conducted as a function of time to determine how aqueous iodine speciation changed after sediment suspensions were amended with either iodide or iodate. Two SRS sediments were used, a wetland sediments, FSI-18, which contained $24.1 \%$ organic carbon (OC), and North Borrow sediment collected from the SRS vadose zone, containing $0.01 \%$ OC. For this report, we will focus on the findings associated with the North Borrow sediment because it is more representative of sediments existing in the vadose and aquifers of the SRS (Table 3). For purposes of comparison, results from the high organic matter wetland sediment, FSI-18 are also presented. 
SRNL-STI-2012-00518

Revision 0

Table 3. Characterization of sediment used by Xu et al. (2011).

\begin{tabular}{|c|c|c|}
\hline Parameters & FSI18 & N Borrow \\
\hline $\mathrm{pH}$ & $5.63 \pm 0.1$ & $5.2 \pm 0.1$ \\
\hline $\mathrm{OM}, \%$ & 24.1 & $<0.01$ \\
\hline Sand/silt/clay (wt\%) & $92.1 / 7.0 / 0.9$ & N/A \\
\hline${ }^{127} \mathrm{I}(\mu \mathrm{g} / \mathrm{g})$ & 4.26 & N/A \\
\hline${ }^{129} \mathrm{I}(\mu \mathrm{g} / \mathrm{g})$ & 0.32 & N/A \\
\hline $\mathrm{FeII} / \mathrm{Fe}(\mathrm{III}), \% / \%$ & N/A & $1.9 / 98.1$ \\
\hline $\mathrm{FeII} / \mathrm{Fe}(\mathrm{III}), \% / \%$ & N/A & $<2 />98$ \\
\hline Fe(III), Hematite, Goethite, (Mossbauer), \% & N/A & $8,28,63$ \\
\hline Reduction Capacity, meq/kg & N/A & $2.88 \pm 0.82$ \\
\hline Mineralogy $(<53 \mu \mathrm{m})$ & N/A & $\begin{array}{l}\text { Kaolinite, goethite, hematite, gibbsite, } \\
\text { muscovite, rutile (no quartz; slight } 14 \AA \text { ) }\end{array}$ \\
\hline $\mathrm{DCB}^{\mathrm{a}} \mathrm{Al},<53 \mu \mathrm{m}(\mathrm{ppm})$ & N/A & $961.9 \pm 78$ \\
\hline DCB Fe, $<53 \mu \mathrm{m}(\mathrm{ppm})$ & N/A & $5346.3 \pm 563$ \\
\hline DCB Mn, $<53 \mu \mathrm{m}(\mathrm{ppm})$ & N/A & $8.8 \pm 1$ \\
\hline
\end{tabular}

${ }^{\mathrm{a}} \mathrm{DCB}=$ dithionite carbonate buffer extraction method providing a measure of surface available (not total) elemental concentrations primarily associated with amorphous and crystalline iron-oxides.

After varying suspension-sediment contact time, the aqueous phase was collected by centrifuging and then passing the supernatant through a $0.45-\mu \mathrm{m}$ membrane. The aqueous phase was further fractionated by passing through a 3000 Dalton $(3 \mathrm{kDa})$ membrane. Iodine speciation of the various aqueous fractions was quantified by the GC-MS method of Zhang et al. (2011). Moist sediment was mixed with artificial SRS groundwater with an ionic strength of $1.64 \mathrm{mM}$ (MINTEQA1 v1.5) $\left(0.23 \mathrm{mM} \mathrm{Na}^{+}, 0.15 \mathrm{mM} \mathrm{Mg}^{2+}\right.$, $0.33 \mathrm{mM} \mathrm{Ca}^{2+}, 0.03 \mathrm{mM} \mathrm{K}^{+}, 0.16 \mathrm{mM} \mathrm{Cl}^{-}, 0.07 \mathrm{mM} \mathrm{SO}_{4}{ }^{2-}$, and $0.86 \mathrm{mM} \mathrm{HCO}_{3}{ }^{-}$) and the $\mathrm{pH}$ adjusted to near neutral by purging $\mathrm{CO}_{2}$ gas. The solid: liquid ratio was 1:4. Uptake (sorption and $\mathrm{OC}$ binding) and transformation of inorganic iodine was observed in five treatments: (1) control (without any iodine addition), 2) $20 \mu \mathrm{M}$ iodide amendment, (3) $20 \mu \mathrm{M}$ iodate amendment, (4) $0.1 \mu \mathrm{M}$ iodide amendment, and (5) $0.1 \mu \mathrm{M}$ iodate amendment. Carrier free ${ }^{125} \mathrm{I}^{-}$and ${ }^{125} \mathrm{IO}_{3}{ }^{-}$were well equilibrated with stable iodine before adding to treatments, as an analogue for ${ }^{129} \mathrm{I}$.

A desorption distribution coefficient, $\mathrm{K}_{\mathrm{d} \text {-desorp, }}$, was determined using the ratio of the concentration of residually sorbed iodine to that in the desorbing solution $(0.1 \mathrm{~N} \mathrm{KCl})$. The purpose of using $0.1 \mathrm{~N} \mathrm{KCl}$ was to promote iodine desorption under extreme conditions to provide an operational measure of the anion exchangeable fraction (i.e., those species bound via outer sphere complexation to the sediment mineral phase through electrostatic interactions). The $\mathrm{K}_{\mathrm{d}}$ and $\mathrm{K}_{\mathrm{d} \text {-desorp }}$ construct is used here to quantify uptake of iodine from the aqueous phase by sediments and does not imply any particular uptake or sorption mechanism.

\subsection{Results and Discussion}

Table 4 provides iodine $\mathrm{K}_{\mathrm{d}}$ values when either iodide or iodate was used as the original spike solution. The distinction is that they are not species specific $\mathrm{K}_{\mathrm{d}}$ values, but instead reflect the total iodine concentration in the solid phase $\left(\mathrm{I}_{\text {total sediment }}\right)$ divided by the total iodine concentration in the aqueous phase $\left(I_{\text {total aq }}\right)$ : 


$$
I K_{d}=\frac{I_{\text {total sediment }}}{I_{\text {total aq }}}
$$

Eq. 1

A species-specific iodide/iodate $K_{d}$ would require use of species concentrations, for example for iodide:

$$
I^{-} K_{d}=\frac{I_{\text {sediment }}^{-}}{I_{\text {aq }}^{-}}
$$

where $\mathrm{I}_{\text {aq }}^{-}$and $\mathrm{I}_{\text {sediment }}^{-}$are the iodide concentrations in the aqueous phase and sediment, respectively. The problem lies in that there are no available analytical techniques for measuring iodine species at sub-ppm levels on the solid phase.

In the low organic-matter content sediment, North Borrow sediment, $\mathrm{K}_{\mathrm{d}}$ values for iodine added at low and high concentrations as iodate $\left(\mathrm{I}_{\text {iodate }}\right)$ was generally about four times greater than those $\mathrm{K}_{\mathrm{d}}$ values in which iodine was added as iodide (Table 4). This is consistent with previous reports (Denham et al., 2009) where $I_{\text {iodate }} K_{d}$ values can be as much as $100 x$ that of $I_{\text {iodide }} K_{d}$ values. Furthermore, the desorption $\mathrm{I}_{\text {iodide }}-$ or $\mathrm{I}_{\text {iodate }}-\mathrm{K}_{\mathrm{d} \text {-desorp }}$ values in the North Borrow sediment were much greater than the (ad)sorption $\mathrm{K}_{\mathrm{d}}$ values, irrespective of iodine species or the total iodine concentration added. This sorption hysteresis is commonly reported and has been attributed to the contaminant diffusing with time into the tiny pores or structure of the solid phase minerals or forming near irreversible covalent bonds to sediment organic matter and consequently not desorbing as readily as it (ad)sorbed to the sediments. For the North Borrow sediment, there was a consistent, but not a large difference in sorption values as the amended iodine concentration decreased (Table 4). Increased $K_{d}$ values with lower iodine concentrations were anticipated because it was previously measured in SRS sediments and attributed to a limited number of "high energy" iodine sorption sites (including organic matter sorption sites) in the sediment and once these relatively few sites were occupied, than the remaining iodine stayed in the aqueous phase, yielding a lower calculated $\mathrm{K}_{d}$ value (Schwehr et al., 2009; Zhang et al., 2011). The high organic matter sediment, FSI-18, had much greater $\mathrm{K}_{\mathrm{d}}$ values than the North Borrow sediment. Sediment organic matter concentrations are commonly the most important sediment characteristic controlling radioiodine sorption (reviewed in Denham et al. 2009) (Xu et al., 2011b; Xu et al., 2011c; Xu et al., 2012). Recently, it has been shown that only slight changes in organic matter concentrations in Hanford Site subsurface sediments resulted in significant changes in iodine $\mathrm{K}_{d}$ values (Kaplan et al., 2012). As will be discussed in more detail in Section 4.3.4, the four day-equilibration period used in the experiment described in Table 4 is sufficient time for the $\mathrm{N}$. Borrow sediment to reach steady state, but probably insufficient time for the FSI-18 sediment to reach steady state. The cause for this difference is that the FSI-18 sediment has significantly more organic matter, promoting numerous kinetically hindered reactions that influence iodine speciation. 


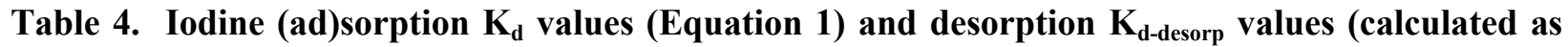
ratios of total iodine in $0.1 \mathrm{~N} \mathrm{KCl}$ extraction solution at equilibrium) at two concentrations $(20 \mu \mathrm{M}$ and $0.1 \mu \mathrm{M}$ ) for the FSI-18 (organic-rich) and North Borrow (organic-poor) sediments, during a four-day contact experiment (values represent averages of duplicates and standard deviation were $<\mathbf{1 0 \% )}$.

\begin{tabular}{|c|c|c|c|c|c|c|c|c|}
\hline & \multicolumn{4}{|c|}{$20 \mu \mathrm{M}$} & \multicolumn{4}{|c|}{$0.1 \mu \mathrm{M}$} \\
\hline & \multicolumn{2}{|c|}{$\mathrm{I}^{-}$} & \multicolumn{2}{|c|}{$\mathrm{IO}_{3}^{-}$} & \multicolumn{2}{|c|}{$\mathrm{I}^{-}$} & \multicolumn{2}{|c|}{$\mathrm{IO}_{3}^{-}$} \\
\hline & $\mathrm{K}_{\mathrm{d}}$ & $\mathrm{K}_{\mathrm{d}-\text { desorp }}$ & $\mathrm{K}_{\mathrm{d}}$ & $\mathrm{K}_{\mathrm{d} \text {-desorp }}$ & $\mathrm{K}_{\mathrm{d}}$ & $\mathrm{K}_{\mathrm{d} \text {-desorp }}$ & $\mathrm{K}_{\mathrm{d}}$ & $\mathrm{K}_{\mathrm{d} \text {-desorp }}$ \\
\hline FSI-18 & 13.82 & 118.45 & 12.40 & 96.67 & 41.21 & 235.69 & 37.98 & 1077.11 \\
\hline N. Borrow & 1.74 & 16.23 & 4.34 & 7.32 & 0.71 & 23.89 & 5.16 & 9.75 \\
\hline
\end{tabular}

Changes in iodine speciation as a function of time when iodide or iodate were added to the North Borrow sediment are presented in Figure 3. For the iodide or iodate amended suspensions, the amount of iodine sorbed onto the sediment reached steady state before the first measurement at 4 days (Figure 3A). All of the aqueous iodine added as iodide could pass through a $3 \mathrm{kDa}$ membrane, suggesting that there was little colloidal or organo-iodine formed. Furthermore, the iodide did not convert to other species during the 32 day period (Figure 3B).

When iodate was added to the sediment, within four days, $20 \%$ of the added iodate had converted to iodide, $<1 \%$ to organo-iodine, and $80 \%$ remained as iodate (Figure 3D). About $40 \%$ of the introduced iodate, was taken up by the sediment (Figure 3C), compared to $\sim 22 \%$ of the iodide taken up by the sediment. As was the case when iodide was added, there was very little detectable organo-iodine in the iodate amended system. Figure 4 shows in a pie chart the iodine speciation after four-days of contact with the North Borrow sediment. Again, the low-organic matter sediment appears to have reached steady state before the first sampling time. 


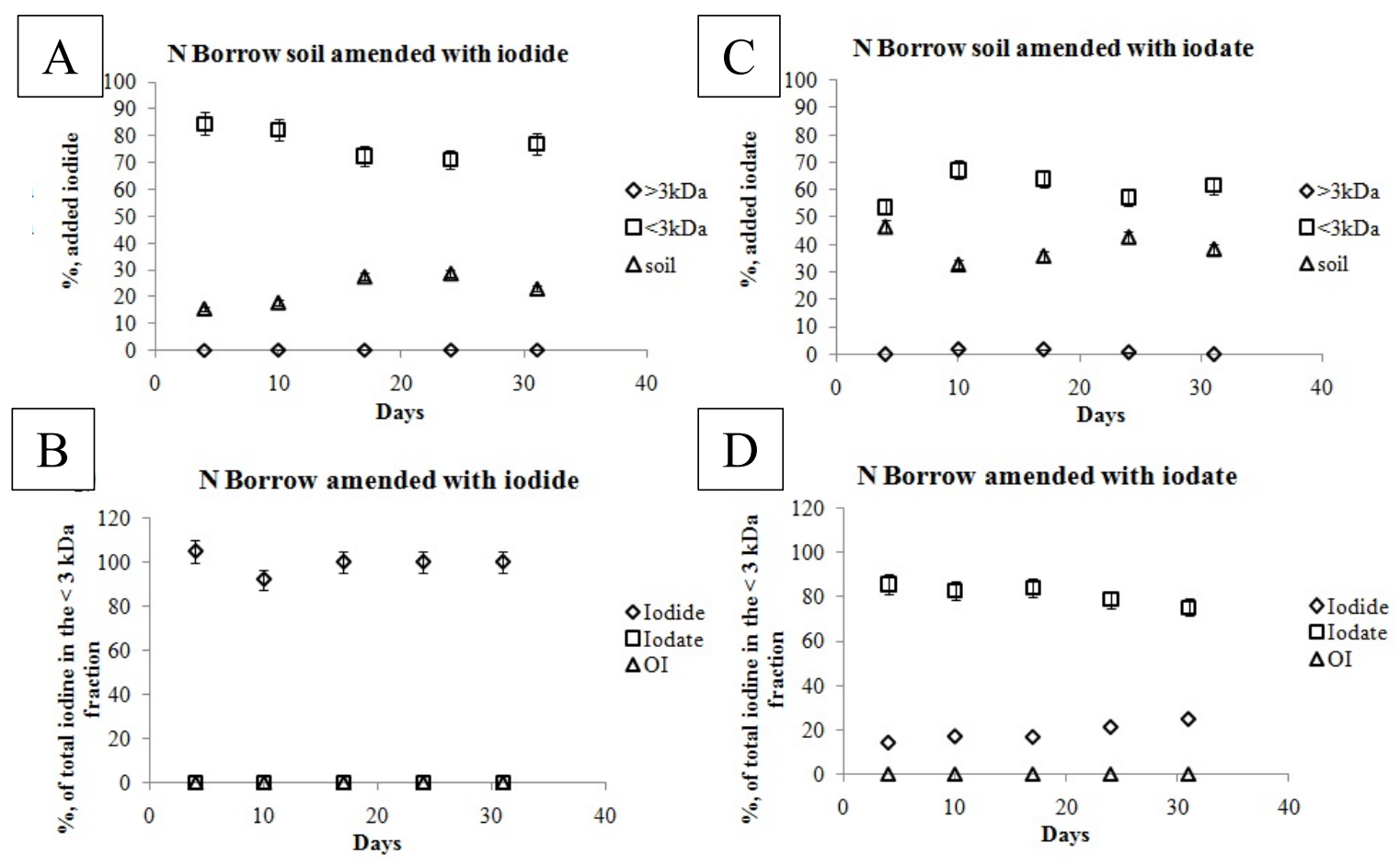

Figure 3. For the iodide-amended North Borrow suspensions: (A) percent aqueous iodide in the $<3 \mathrm{kDa}$ fraction, $>3 \mathrm{kDa}$ fraction, and associated with the sediment; and (B) percent aqueous iodide, iodate, and organo-iodine (OI). For the iodate-amended North Borrow suspensions: (C) percent aqueous iodide in the $<3 \mathrm{kDa}$ fraction, $>3 \mathrm{kDa}$ fraction, and associated with the sediment; and (D) percent aqueous iodide, iodate, and organo-iodine (OI). 


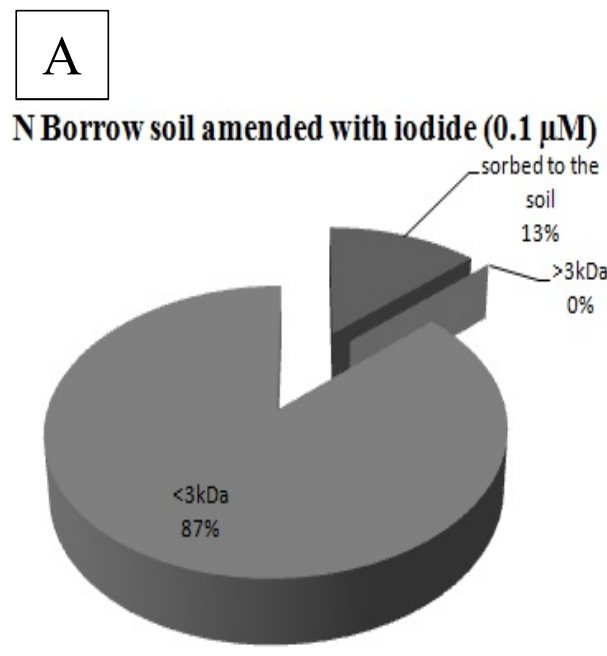

\section{B}

N Borrow soil amended with iodate $(0.1 \mu \mathrm{M})$

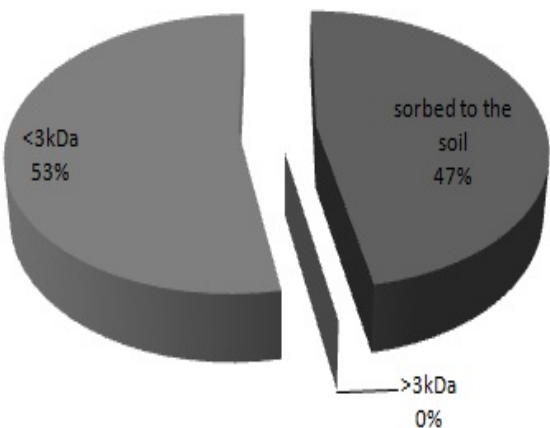

Figure 4. Iodine size fractionation after contact with the North Borrow sediment for four days when amended with (A) iodide or (B) iodate.

\subsection{Implications of these results for SRS performance assessments}

- $\mathrm{K}_{\mathrm{d}}$ values of iodate are much greater than those for iodide.

- Once iodide was added to the SRS subsurface sediment, negligible amounts of iodate were formed. Conversely, when iodate was added to the sediment, about $20 \%$ of it remained as iodate. Due to the very low sediment organic matter concentrations, little organo-iodine was observed in the aqueous phase.

- Desorption $\mathrm{K}_{\mathrm{d}}$ values were 4 to 5 times greater than (ad)sorption $\mathrm{K}_{\mathrm{d}}$ values. All previous laboratory measurements of ${ }^{129} \mathrm{I}-\mathrm{K}_{\mathrm{d}}$ values were (ad)sorption values. Desorption $\mathrm{K}_{\mathrm{d}}$ values, describing the slower (or rate-limiting) reaction, would reflect better the overall reactions occurring during subsurface transport.

\subsection{Iodine $K_{d}$ Values as a Function of $\mathbf{p H}$, Reducing or Oxidizing Conditions, and Iodide or Iodate Additions to Subsurface Sediments}

\subsection{Introduction}

There are a wide range of conditions expected in the subsurface environment, especially in the near field where the waste form may influence the aqueous chemistry. It is valuable to understand how iodine $\mathrm{K}_{\mathrm{d}}$ values change under these varied conditions. Lilley et al. (2010) and Emerson et al. (2012) conducted a series of (ad)sorption batch tests under four conditions:

1) Iodide additions under oxidizing conditions (conducted on the lab bench),

2) Iodide additions under reducing conditions (conducted in a $\mathrm{N}_{2} / \mathrm{H}_{2}$ glovebox), 
3) Iodate additions under oxidizing conditions (conducted on the lab bench),

4) Iodate additions under reducing conditions (conducted in a $\mathrm{N}_{2} / \mathrm{H}_{2}$ glovebox),

For each of these conditions, $\mathrm{I} \mathrm{K}_{\mathrm{d}}$ values were measured as a function of $\mathrm{pH}$, contact time, and sediment type (clayey and organic sediments and in select experiments, a sandy sediment was also investigated). The emphasis of this report will be to discuss the results involving the subsurface clayey and sandy sediments and not the high organic matter wetland sediment.

\subsection{Materials and Methods}

The subsurface clayey and subsurface sandy sediments used in this study were collected from the Tobacco Road Formation in E-Area and the Four Mile Branch wetland sediment was collected along the creek edge in F-Area of the SRS (Table 5).

Table 5. Sediment characterization.

\begin{tabular}{|c|c|c|c|}
\hline PARAMETER $^{\text {a }}$ & Subsurface Clayey & Subsurface Sandy & $\begin{array}{c}\text { Four Mile } \\
\text { Branch Wetland }\end{array}$ \\
\hline$\%$ sand $(53 \mu \mathrm{m}-2 \mathrm{~mm})$ & 57.9 & 97 & 85.5 \\
\hline$\%$ silt $(53-2 \mu \mathrm{m})$ & 40.6 & 2.9 & 11.7 \\
\hline$\%$ clay $(<2 \mu \mathrm{m})$ & 1.6 & 0.2 & 2.8 \\
\hline Textural classification & Silty clay & Sand & \\
\hline $\mathrm{pH}$ & 4.55 & 5.10 & 4.10 \\
\hline Organic Carbon (wt-\%) & 1.2 & 0 & 9.7 \\
\hline $\mathrm{CEC}(\mathrm{cmol} / \mathrm{kg})$ & $1.09 \pm 0.31$ & $<0.05$ & \\
\hline $\mathrm{AEC}(\mathrm{cmol} / \mathrm{kg})$ & $1.58 \pm 0.61$ & $0.06 \pm 0.19$ & \\
\hline BET surface area $\left(\mathrm{m}^{2} / \mathrm{g}\right)$ & 15.3 & 1.27 & 3.76 \\
\hline Point of Zero Charge pH & 5.65 & & 4.01 \\
\hline $\mathrm{CDB}$ extractable $\mathrm{Fe}(\mathrm{mg} / \mathrm{g})$ & 15.3 & 7.06 & \\
\hline $\mathrm{Al}(\mathrm{ppm})$ & 63.6 & 16.6 & \\
\hline $\mathrm{Na}(\mathrm{ppm})$ & 42.9 & 34.7 & \\
\hline $\mathrm{Mg}(\mathrm{ppm})$ & 144 & 98.8 & \\
\hline $\mathrm{Ca}(\mathrm{ppm})$ & 64.4 & 24.6 & \\
\hline $\mathrm{K}(\mathrm{ppm})$ & 183 & 93.0 & \\
\hline Mineralogy & $\begin{array}{c}\text { Kaolinite, goethite, } \\
\text { hematite }\end{array}$ & 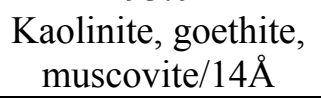 & \\
\hline
\end{tabular}

Batch sorption experiments were performed in $15 \mathrm{~mL}$ BD Falcon conical tubes, containing $25 \mathrm{~g} / \mathrm{L}$ of clayey or wetland sediments in $0.01 \mathrm{M} \mathrm{NaCl}$. The suspensions were amended with 1000 or $10,000 \mathrm{ppb}$ of iodate and iodide. For the $\mathrm{pH}$-dependence studies, the $\mathrm{pH}$ of each tube was adjusted at the time the sediment suspensions were spiked with $1000 \mathrm{ppb}$ or $10,000 \mathrm{ppb}$ of iodide or iodate and re-adjusted three days later. After the third day, all samples were allowed to equilibrate without further $\mathrm{pH}$ adjustment and the final $\mathrm{pH}$ was reported. Several control samples were included with these samples: 1) sediment-free controls (to provide an estimate of the amount of iodide/iodate added to the system), 2) iodine blanks (to 
provide an estimate of the natural iodine that desorbed from the sediment), and 3) eight samples following the $\mathrm{pH}$ range of 3.5 to 7.0 with an approximate step of $0.5 \mathrm{pH}$ units.

For the concentration dependence studies, iodate or iodide was spiked into the sediment suspensions at concentrations of 500,1000,2000,5000, and 10,000 ppb along with sediment-free controls. The actual sediment-containing samples were not adjusted for $\mathrm{pH}$ but were allowed to equilibrate with the sediments. At the end of the study, the $\mathrm{pH}$ values were approximately 4.5 in the wetland sediment suspensions and 4.7 in the clayey sediment suspensions. The $\mathrm{pH}$-dependent samples prepared on the bench top were considered the aerobic batch sorption experiments. The anaerobic batch sorption studies were prepared entirely within a glovebox (Coy Laboratories) with a $98 \% \mathrm{~N}_{2} / 2 \% \mathrm{H}_{2}$ gas mixture, to minimize exposure to oxygen. For the anaerobic system, the sediments were allowed to dry within the glovebox before preparation to ensure that oxygen was not present. Each sample was suspended in $0.01 \mathrm{NaCl}$, amended with the appropriate iodide or iodate concentration, then placed on a Labquake (Thermo Scientific) rotary shaker table set at 8 revolutions/min and allowed to equilibrate for 12 weeks. At the end of the equilibration period, the samples were removed from the shaker, the $\mathrm{pH}$ was measured, and then the solid and aqueous phases were separated by centrifuging at $8000 \mathrm{rpm}$ for 30 minutes, followed by $0.1 \mu \mathrm{M}$ filtration.

Total iodine concentrations were measured on the centrifuged/filtered aqueous phase samples by ICPMS (Thermo X-series II ICP-MS). About $1 \mathrm{~mL}$ of the supernatant was removed from the centrifuge tube and placed into a $15 \mathrm{~mL}$ BD Falcon test tube with $9 \mathrm{~mL}$ of Trap solution. The Trap solution was used to reduce iodine species to iodide, reduce interference from similar elements and background, and raise/buffer the $\mathrm{pH}$ to keep $\mathrm{I}_{2}(\mathrm{~g})$ species from forming. The Trap solution was composed of $1 \%$ CFAC (Spectrasol, Inc.), 1\% tetramethylammonium hydroxide (Alfa Aesar), and $0.005 \mathrm{M} \mathrm{Na}_{2} \mathrm{SO}_{3}$ (VWR). Throughout the experiments, the detection limit was between $1.0 \mathrm{ppb}(7.8 \mathrm{e}-9 \mathrm{M})$ and $2.5 \mathrm{ppb}(1.9 \mathrm{e}-8 \mathrm{M})$.

The sediment concentration was calculated after determination of aqueous concentration by ICP-MS using the following equation:

$$
[I]_{\text {sed }}=\frac{\left([I]_{a q, i}-[I]_{a q, t}\right) V_{L}}{m_{\text {sed }}}
$$

where: $\quad[\mathrm{I}]_{\mathrm{sed}}=$ total iodine concentration in sediment, $\mathrm{ppb}$

$[\mathrm{I}]_{\mathrm{aq}, \mathrm{i}}=$ initial total aqueous iodine concentration, $\mathrm{ppb}$

$[\mathrm{I}]_{\mathrm{aq}, \mathrm{t}}=$ total aqueous iodine concentration at time, $\mathrm{t}, \mathrm{ppb}$

$\mathrm{V}_{\mathrm{L}}=$ sample liquid volume, $\mathrm{mL}$

$\mathrm{m}_{\text {sed }}=$ sample sediment mass, $\mathrm{g}$

Iodine $\mathrm{K}_{\mathrm{d}}$ values were calculated by first estimating the iodine associated with the sediments using Equation 3, and then using that value in the numerator of Equation 1. As such an iodine $\mathrm{K}_{\mathrm{d}}$ value and not a species specific $K_{d}$ value were estimated with Equation 1 and 3. More specifically, the iodine $K_{d}$ values were estimated when either iodide or iodate were initially added to the suspension, yielding $\mathrm{I}_{\text {iodide }}$ or $\mathrm{I}_{\text {iodate }}$ $\mathrm{K}_{\mathrm{d}}$ values. They provide the most useful measure of how radioiodine will partition between aqueous and solid phases, albeit, with less understanding than a species-specific $\mathrm{K}_{\mathrm{d}}$ value. Because the geochemistry in the PA does not track iodine at the species level, general iodine $\mathrm{K}_{\mathrm{d}}$ values provide the best direct input values for PA modeling. 
SRNL-STI-2012-00518

Revision 0

\subsection{Results and Discussion}

\subsubsection{Iodine Added as Iodate (I $\left.I_{\text {iodate }}\right)$ Sorption to Clayey Sediments under Aerobic Conditions}

$\mathrm{I}_{\text {iodate }} \mathrm{K}_{\mathrm{d}}$ values were estimated for clayey sediment suspensions maintained under aerobic conditions between $\mathrm{pH} 3.5$ and 7.0 (Figure 5). They were also estimated for relatively constant $\mathrm{pH}$ but variable iodate-amended concentrations, ranging from 500 and 10,000 ppb (Figure 6). Iodine sorption decreased sharply as the $\mathrm{pH}$ increased from $\mathrm{pH} 3.5$ to 7 (Figure 5). Iodine sorption remained relatively linear at aqueous concentrations $<4000 \mathrm{ppb}$, supportive of the use of the $\mathrm{K}_{\mathrm{d}}$ construct over this concentration range (Figure 6). Not tested is whether this apparent linearity exists at much lower iodine concentrations, e.g., between 0 and $20 \mathrm{ppb}$. Background concentrations of stable ${ }^{127} \mathrm{I}$ on the Savannah River Site is between 2 and 12 ppb (Millings et al., 2003).

$\mathrm{I}_{\text {iodate }}$ sorption to the clayey sediment was very time sensitive between one and seven days; such that after one day the $\mathrm{K}_{\mathrm{d}}$ was $13 \mathrm{~mL} / \mathrm{g}$, after three days it was $50 \mathrm{~mL} / \mathrm{g}$, and after seven days, it was $117 \mathrm{~mL} / \mathrm{g}$ (Figure 6). The cause for this solute sorption kinetics may be attributed to changes in speciation, time required to diffuse into the sample, and/or time required for the solute to make contact with solid-phase sorption sites. Finally, the $\mathrm{K}_{\mathrm{d}}$ values for the iodate-amended clayey sediment (Figure 5 and Figure 6) were more than an order of magnitude lower than those for the wetland sediments (data presented in Appendix A, Figure 15 and Figure 16).

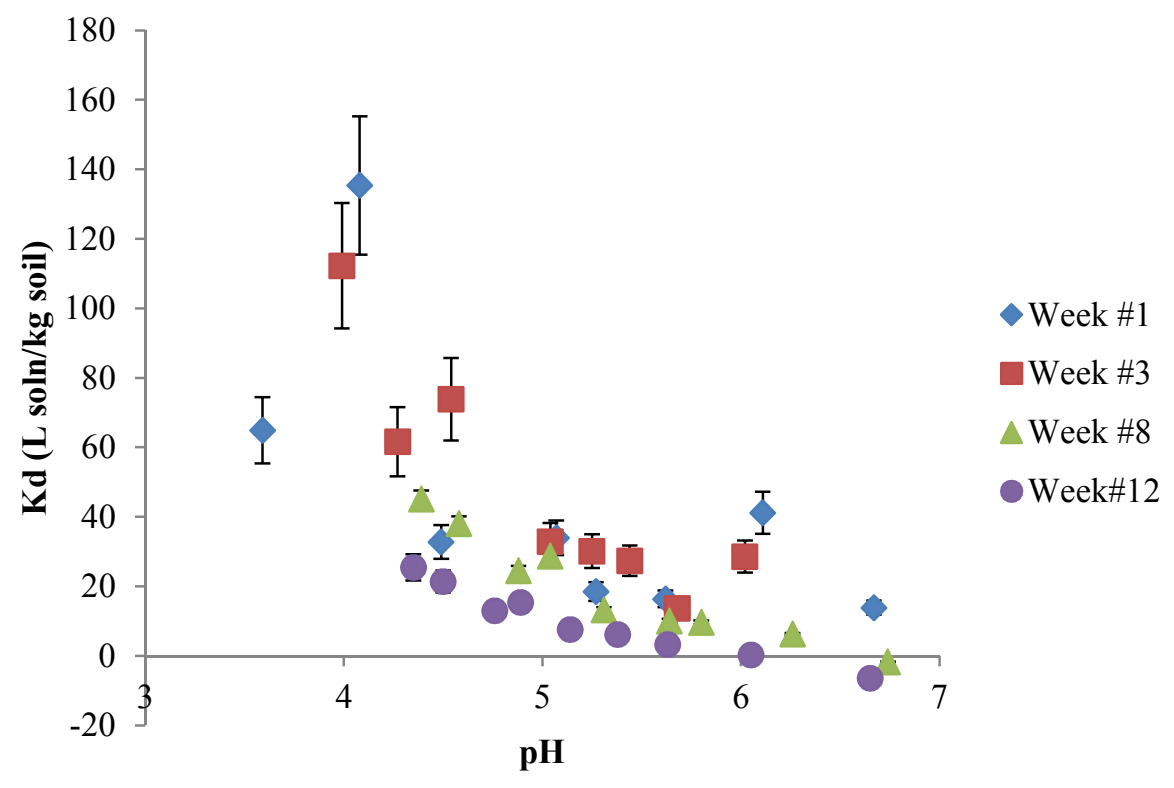

Figure 5. Iodine added as iodate $\mathrm{K}_{d}$ values (Equation 1) to clayey sediment suspensions under variable $\mathrm{pH}$ aerobic conditions (1000 ppb total iodine, $25 \mathrm{~g} / \mathrm{L}$ sediment in $0.01 \mathrm{M} \mathrm{NaCl}$ ). 
Revision 0

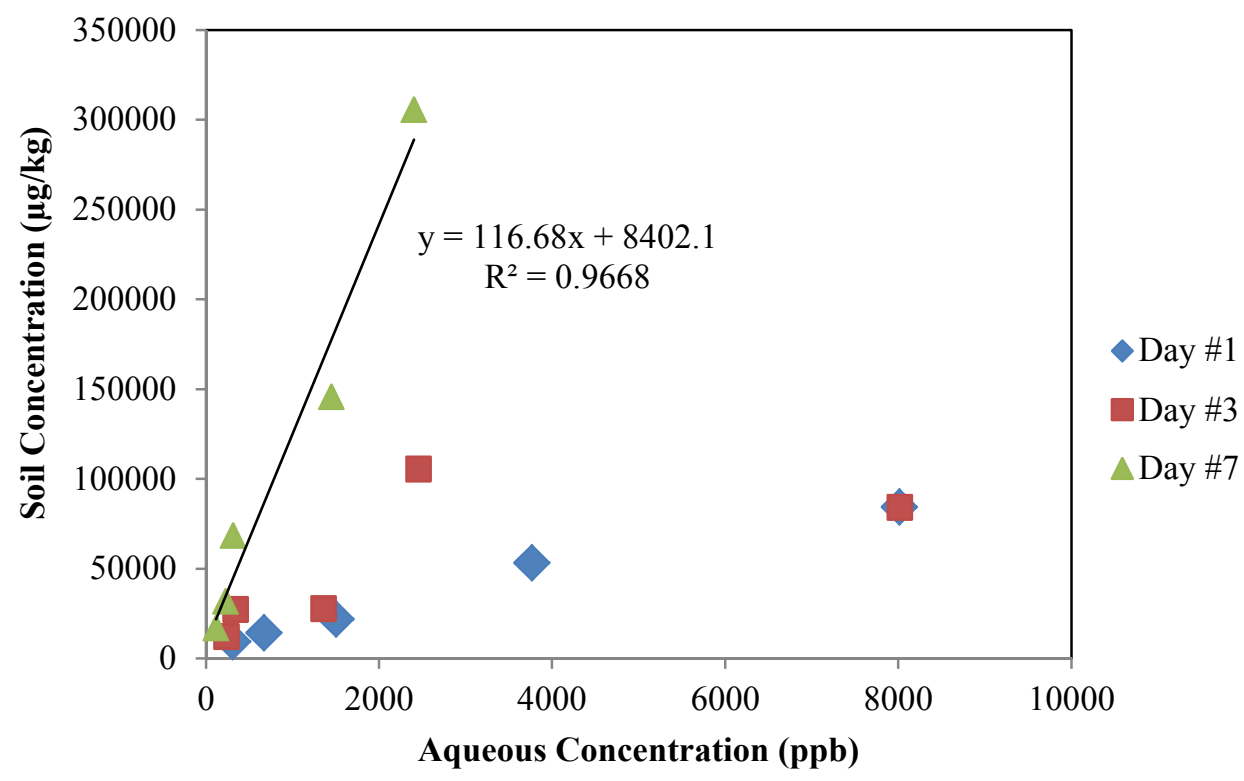

Figure 6. Iodine added as iodate $\mathrm{K}_{\mathrm{d}}$ values to clayey sediment suspensions in aerobic conditions with variable total iodine concentrations and contact times $(\mathrm{pH} \sim 4.7,25 \mathrm{~g} / \mathrm{L}$ sediment in $0.01 \mathrm{M} \mathrm{NaCl})$.

\subsubsection{Iodine Added as Iodide (I $\left.I_{\text {iodide }}\right)$ Sorption to Clayey Sediments under Aerobic Conditions}

In the iodide-amended clayey sediment system, there was a decrease in sorption as the $\mathrm{pH}$ increased (Figure 7). Again, the effect of natural iodine (as opposed to amended iodine) desorption from the sediments is evident by the presence of negative $K_{d}$ values. 
SRNL-STI-2012-00518

Revision 0

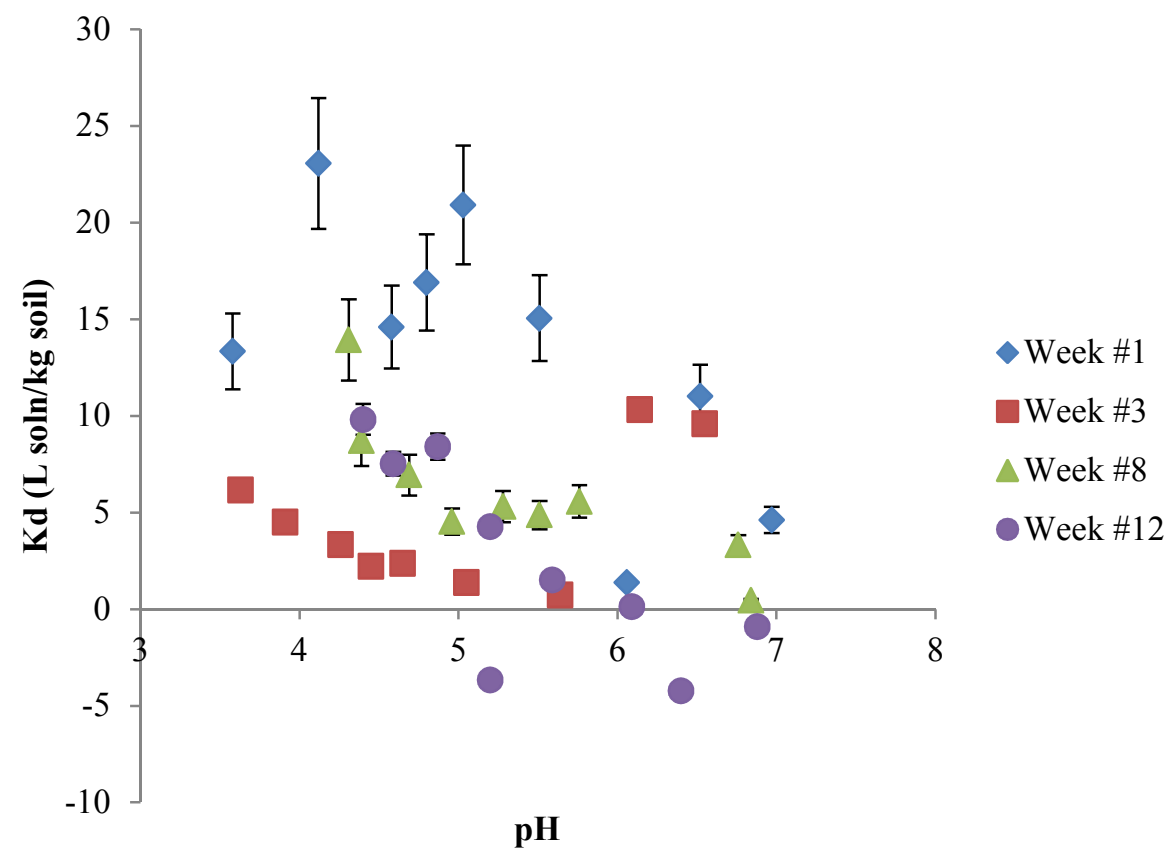

Figure 7. Iodine added as iodide $\left(\mathrm{I}_{\text {iodide }}\right) \mathrm{K}_{\mathrm{d}}$ values in clayey sediment suspensions under variable-pH, aerobic conditions (1000 ppb total iodine, $25 \mathrm{~g} / \mathrm{L}$ sediment in $0.01 \mathrm{M} \mathrm{NaCl}$ ) (values not corrected for natural iodine desorption from sediment slightly increasing reported $\mathrm{K}_{\mathrm{d}}$ ).

There was an interaction between the $\mathrm{pH}$ effect and time on $\mathrm{K}_{\mathrm{d}}$ values (Figure 8). Both $\mathrm{I}_{\text {iodide }}$ and $\mathrm{I}_{\text {iodate }}$ sorbed more to the clayey sediment under low $\mathrm{pH}$ conditions than under elevated $\mathrm{pH}$ conditions (Figure 8). Also, $\mathrm{I}_{\text {iodate }}$ initially sorbed appreciably more to the clayey sediments than $\mathrm{I}_{\text {iodide }}$ (Figure 8). At $\mathrm{pH} 4.3$, the $\mathrm{I}_{\text {iodate }} \mathrm{K}_{\mathrm{d}}$ was $45 \mathrm{~mL} / \mathrm{g}$ and decreased to negligible sorption at $\mathrm{pH}>6.7$. By comparison, the greatest $\mathrm{I}_{\text {iodide }} \mathrm{K}_{\mathrm{d}}$ value after eight weeks was at $\mathrm{pH} 4.3$, but was only $10 \mathrm{~mL} / \mathrm{g}$. After eight weeks, the $\mathrm{pH}$ had a significantly greater impact on the $I_{\text {iodate }} K_{d}$ values, decreasing $I_{\text {iodate }} K_{d}$ values by $22 \mathrm{~mL} / \mathrm{g}$ for each pH unit increase between 4.4 and 6.75. By comparison, the iodide-amended system had a $3.6 \mathrm{~mL} / \mathrm{g}$ decrease in $\mathrm{K}_{\mathrm{d}}$ values per unit increase in $\mathrm{pH}$ in this range. Iodine sorption in both the iodate- and iodideamended systems had negligible sorption above $\mathrm{pH}$ 6.75. After equilibrating for 12 weeks, the $\mathrm{I}_{\text {iodate }} \mathrm{K}_{\mathrm{d}}$ values greatly decreased, and had $\mathrm{K}_{\mathrm{d}}$ values indistinguishable from the 12 week iodide-amended system. As described in Section 3.3, a fraction of the iodate quickly converts (chemically reduces) to iodide when put in contact with an SRS subsurface sediment under aerobic conditions (Figure 3 and Figure 4). Under similar bench top aerobic conditions for 31 days, $17 \%$ of the iodate had converted to iodide and $22 \%$ had converted to iodide (Figure 3) (Xu et al., 2011a). Conversely, negligible oxidation of iodide to iodate was reported (Figure 3) (Xu et al., 2011a). 
SRNL-STI-2012-00518

Revision 0

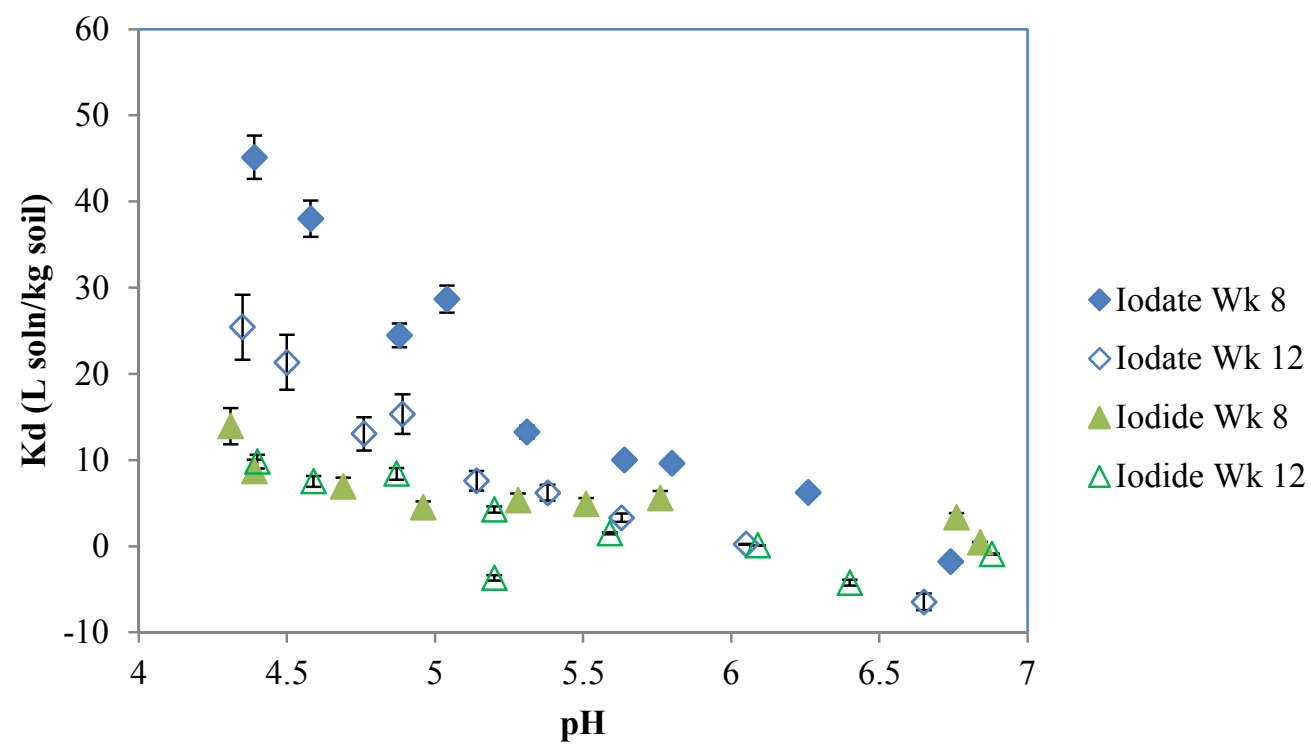

Figure 8. Comparison of iodine sorption in $\mathrm{IO}_{3}{ }^{-}$and $\mathrm{I}^{-}$amended clayey sediment suspensions under aerobic and variable $\mathrm{pH}$ conditions after 8 and 12 weeks of equilibration $\left(1000 \mathrm{ppb} \mathrm{I}_{\text {total }}, 25 \mathrm{~g} / \mathrm{L}\right.$ sediment in $0.01 \mathrm{M} \mathrm{NaCl}$ ) (values not corrected for natural iodine desorption from sediment slightly increasing reported $\mathrm{K}_{\mathrm{d}}$ ).

Several negative $K_{d}$ values were measured (Figure 8 ). This is the result of an aqueous iodine recovery greater than $100 \%$ for the initial aqueous concentration during the sampling event, signifying that some naturally occurring iodine desorbed from the sediment. This behavior is commonly observed for very weakly bound analytes and when a naturally occurring solute is used to amend the sediment. For this reason, non-naturally occurring isotopes, such as ${ }^{125} \mathrm{I}$ or ${ }^{129} \mathrm{I}$, are commonly used in iodine studies. In these experiments, as much as $120 \%$ iodine recovery was measured in systems where negative $\mathrm{K}_{\mathrm{d}}$ values are reported. Consequently, the negative $\mathrm{K}_{\mathrm{d}}$ values are likely an experimental artifact and may not indicate the existence of anion exclusion (Kaplan and Serne, 1998). $\mathrm{K}_{\mathrm{d}}$ values were generally greater when higher iodine concentrations were used (Figure 9). This data is presented to provide insight into the trends expected between contact time, iodine species added, and $\mathrm{pH}$. As was the case with the iodate-amended sorption studies, the sorption isotherms were relatively linear below $400 \mathrm{ppb}$ iodide; the correlation coefficient was 0.93 after seven days of contact (Figure 9). 
SRNL-STI-2012-00518

Revision 0

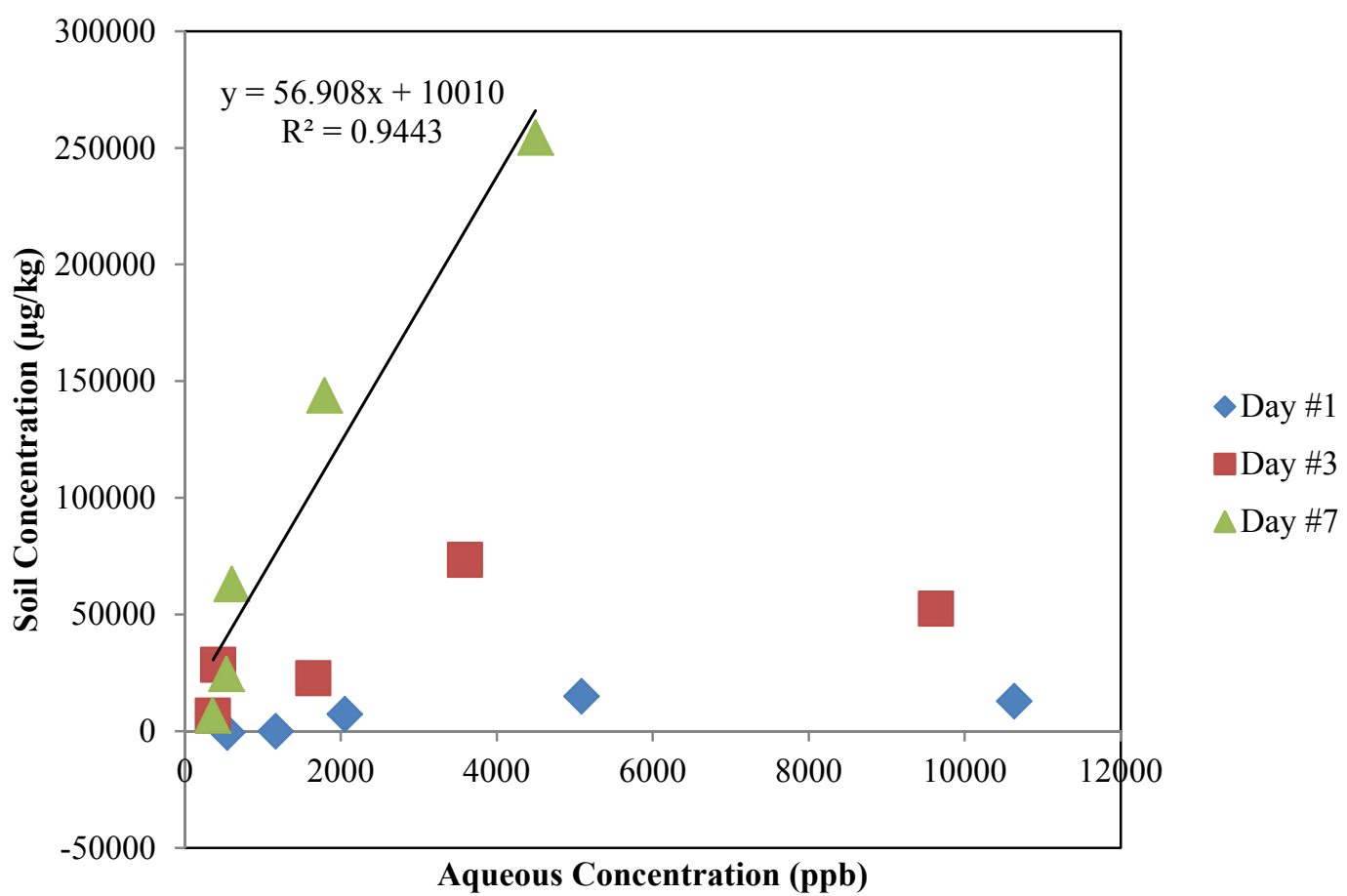

Figure 9. Iodine added as iodide $\left(\mathrm{I}_{\text {iodide }}\right)$ to clayey sediment suspensions in aerobic conditions with variable total iodine concentrations $(\mathrm{pH} \sim 4.7,25 \mathrm{~g} / \mathrm{L}$ sediment in $0.01 \mathrm{M} \mathrm{NaCl})$.

\subsubsection{Influence of Concentration Dependent Studies}

The variable concentration studies provided a measure of how total aqueous iodine concentrations changed as a function of amendment concentration, time, and iodine species. It is noteworthy that the clayey sediments more closely followed a linear sorption isotherm, whereas the wetland sediments followed a Freundlich isotherm (Figure 10 and Table 6) based on comparison of correlation coefficients. However, both models provided acceptable correlation coefficients. Non-linearity was greater for iodate than iodide and may be the result of a limited number of reactive sites within the sediments. The lower concentration range appears to be linear in all cases. This is consistent with the idea that the non-linearity stems from sorption site limitations. 
SRNL-STI-2012-00518

Revision 0

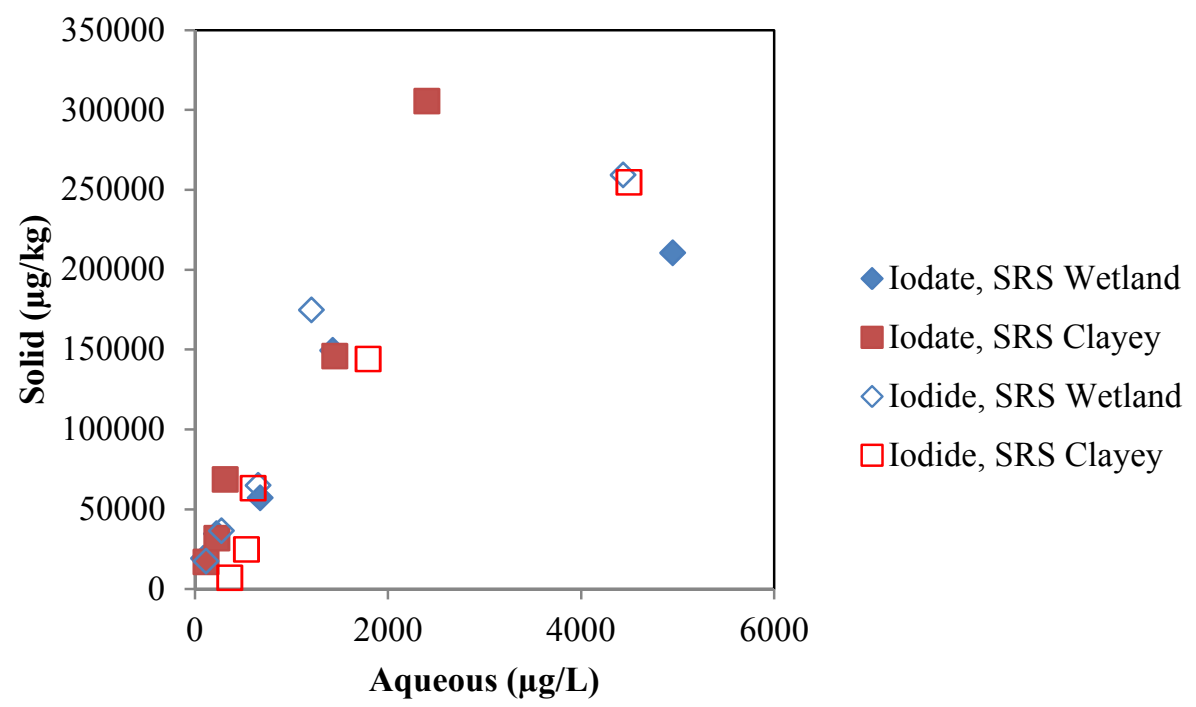

Figure 10. Iodine added as iodide and iodate sorption to a clayey and wetland sediment after seven days with linear $\left(\mathrm{I}_{\text {iodate }} \mathrm{K}_{\mathrm{d}}\right)$ and Freundlich fitted curves.

Table 6. Summary of Freundlich and linear model fits for concentration dependent isotherms at $0.01 \mathrm{M}$ $\mathrm{NaCl}$ after 7 days

\begin{tabular}{ccccc}
\hline Isotherm & Linear & \multicolumn{2}{c}{ Freundlich } \\
& Equation & $\mathrm{R}^{2}$ & Equation & $\mathrm{R}^{2}$ \\
\hline Iodate, SRS Wetland & $\mathrm{Y}=38 \mathrm{x}+38700$ & 0.85 & $\mathrm{Y}=1177 \mathrm{x}^{0.62}$ & 0.96 \\
Iodate, SRS Clayey & $\mathrm{Y}=117 \mathrm{x}+8402$ & 0.97 & $\mathrm{Y}=289 \mathrm{x}^{0.88}$ & 0.96 \\
Iodide, SRS Wetland & $\mathrm{Y}=53 \mathrm{x}+39380$ & 0.85 & $\mathrm{Y}=485 \mathrm{x}^{0.77}$ & 0.95 \\
Iodide, SRS Clayey & $\mathrm{Y}=57 \mathrm{x}+10010$ & 0.94 & $\mathrm{Y}=8.8 \mathrm{x}^{1.26}$ & 0.83 \\
\hline
\end{tabular}

\subsubsection{Influence of Reducing and Oxidizing Conditions on Iodine Sorption to Iodide and Iodate Amended Sediment Suspensions}

To evaluate the effect of reducing and oxidizing conditions on iodine sorption, three sediments were amended with either iodide or iodate and aqueous iodine concentrations $\mathrm{pH}$ and Eh were monitored over eight days.

Iodine Added as Iodide ( $\mathrm{I}_{\text {iodide }}$ ) Sorption to Sediments under Oxidizing Conditions. A plot of the iodine $\mathrm{K}_{\mathrm{d}}$ values for iodide amended sediments is present in Figure 101. As expected, the sandy sediment experienced the least amount of sorption, followed by the clayey, and the wetland had the most sorption. However, what is surprising is at steady state, there is not a significant difference in the $\mathrm{K}_{\mathrm{d}}$ values between the sandy and clayey sediments. What is apparent is the wetland sediments took longer to reach steady state than either the sandy or the clayey sediments, suggesting that delay in reaching equilibrium was the result of diffusion processes. 
SRNL-STI-2012-00518

Revision 0

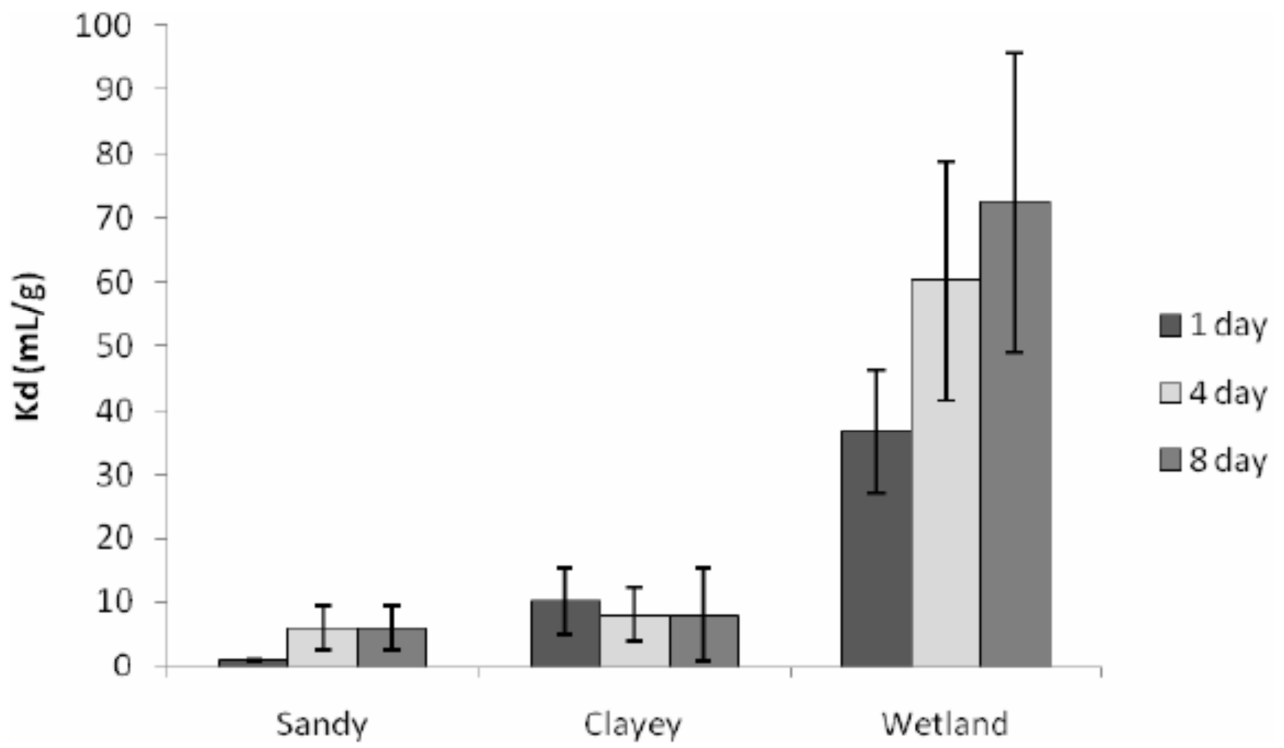

Figure 11. Iodine added as iodide $K_{d}$ values after 1,4 , and 8 days for sediments under oxidizing conditions. Error bars represent average and standard deviation of $K_{d}$ values of five or six samples with varying initial concentrations.

Table 7 shows the redox conditions for the sediments conducted under oxidizing (bench top) conditions. The system became increasingly oxidized over the course of the eight days, with or without sediment in the system. The sediments increased the $\mathrm{E}_{\mathrm{h}}$ with respect to the sediment-free control. The sandy sediment is only slightly more oxidizing than the control. The wetland sediment is more oxidizing than the sandy, but less than the clayey.

Table 7. $E_{h}$ measurements for sediments under aerobic conditions.

\begin{tabular}{cccc}
\hline Sample & ${\text { 1 Day } \mathbf{E}_{\mathbf{h}}(\mathbf{m V})}$ & 4 Day $\mathbf{E}_{\mathbf{h}}(\mathbf{m V})$ & $\mathbf{8}$ Day $\mathbf{E}_{\mathbf{h}}(\mathbf{m V})$ \\
\hline Control (sediment free) & 219 & 235 & 250 \\
Sandy & 185 & 269 & 276 \\
Clayey & 251 & 294 & 355 \\
Wetland & 267 & 297 & 320 \\
\hline
\end{tabular}

Iodine Added as Iodide ( $\mathrm{I}_{\text {iodide }}$ ) Sorption to Sediments under Reducing Conditions. Under anaerobic conditions (a $\mathrm{N}_{2} / \mathrm{H}_{2}$ glovebox system with a $2 \% \mathrm{H}_{2}(\mathrm{~g})$ partial pressure), the $\mathrm{E}_{\mathrm{h}}$ decreased significantly (Table ) with respect to comparable systems under oxidizing conditions (Table ). As was the case under oxidizing conditions (Table ), the sediments tended to increase the $\mathrm{E}_{\mathrm{h}}$, having an overall oxidizing effect, compared to the sediment-free controls. The wetland sediments became the most reducing, likely the result of greater natural organic matter and microbial activity present in this sample. The control and the sandy sediment were a little more oxidizing, but still had a negative potential. After eight days, the clayey sediment remained the most oxidizing, and is the only sediment to have a positive potential. 
SRNL-STI-2012-00518

Revision 0

Table 8. $E_{h}$ measurements for sediments under anaerobic conditions.

\begin{tabular}{cccc}
\hline Sample & $\mathbf{~}_{\text {Day }} \mathbf{E}_{\mathbf{h}}(\mathbf{m V})$ & $\mathbf{4}$ Day $\mathbf{E}_{\mathbf{h}}(\mathbf{m V})$ & $\mathbf{8}$ Day $\mathbf{E}_{\mathbf{h}}(\mathbf{m V} \mathbf{)}$ \\
\hline Control (sediment free) & 78.1 & 44.2 & -39.0 \\
Sandy & 102 & 114 & -34.7 \\
Clayey & 101 & 113 & 44.2 \\
Wetland & 105 & 82.4 & -47.6 \\
\hline
\end{tabular}

The average $I_{\text {iodide }} K_{d}$ values to three sediments under reducing conditions are presented in Figure 12. As was the case under oxidizing conditions, there was no sorption to the sandy sediment after the $1^{\text {st }}$ day, but steady state was reached by day 4 with a $K_{d}$ value of about $8 \mathrm{~mL} / \mathrm{g}$. There was some initial sorption to the clayey sediment, but the error associated with these $K_{d}$ values at 1,4 , and 8 days was too large to conclude if or when steady state was reached. For the wetland sediment, there was strong sorption at day 1 , the $\mathrm{K}_{\mathrm{d}}$ value was $20 \mathrm{~mL} / \mathrm{g}$. The iodine in the wetland sediment suspension appears to have reached steady state by day 4 , but like the clayey sediment, the $\mathrm{K}_{\mathrm{d}}$ values decreased after 8 days of contact (Figure 12). The seemingly elevated 4 day $K_{d}$ values correspond with loss of iodine in solid free control sample. The decrease in $\mathrm{K}_{\mathrm{d}}$ values at day 8 may, in part, be attributed to native iodine being released from the sediments, thereby contributing to the aqueous iodine concentration. In an attempt to correct for this, triplicate unamended samples were used to monitor the release of native iodide from the sediments. The resulting average aqueous iodine concentrations were $12 \pm 1.8,24 \pm 0.9$, and $34 \pm 3.3 \mathrm{ppb}$ at 1 , 4 , and 8 days respectively. These concentrations were then subtracted from the measured aqueous concentrations to minimize any effect the native iodine might have. This would have the most significant effect on the calculated $\mathrm{K}_{\mathrm{d}}$ values from the $100 \mathrm{ppb}$ iodide-amended samples, accounting for about a third of the spike iodide concentration. It appears the average equilibrium $\mathrm{K}_{\mathrm{d}}$ values for the sandy and clayey sediments did not differ significantly, whereas the wetland sediment had a much greater $\mathrm{K}_{\mathrm{d}}$ value under oxidizing conditions (Table ). Additionally, Table 9 shows the steady state $\mathrm{I}_{\text {iodide }} \mathrm{K}_{\mathrm{d}}$ values for the sandy and clayey sediment samples are statistically similar under oxidizing and reducing conditions. However, there is a difference between the oxidizing and reducing wetland sediment steady state $\mathrm{K}_{\mathrm{d}}$ values (Table ). For the wetland sediment, the $I_{\text {iodide }} K_{d}$ values under oxidizing conditions are 4 to 5 times greater than the comparable values under reducing conditions. These data do not provide any indication as to what mechanism may be responsible for the difference in iodide sorption to the wetland sediment under oxidizing and reducing conditions. Oxidation of iodide to iodate in the SRS subsurface is actively being studied, and it has been found that under ambient wetland conditions, natural microbes can promote iodide oxidation to iodate, the stronger sorbing species (Li et al., 2010). 
SRNL-STI-2012-00518

Revision 0

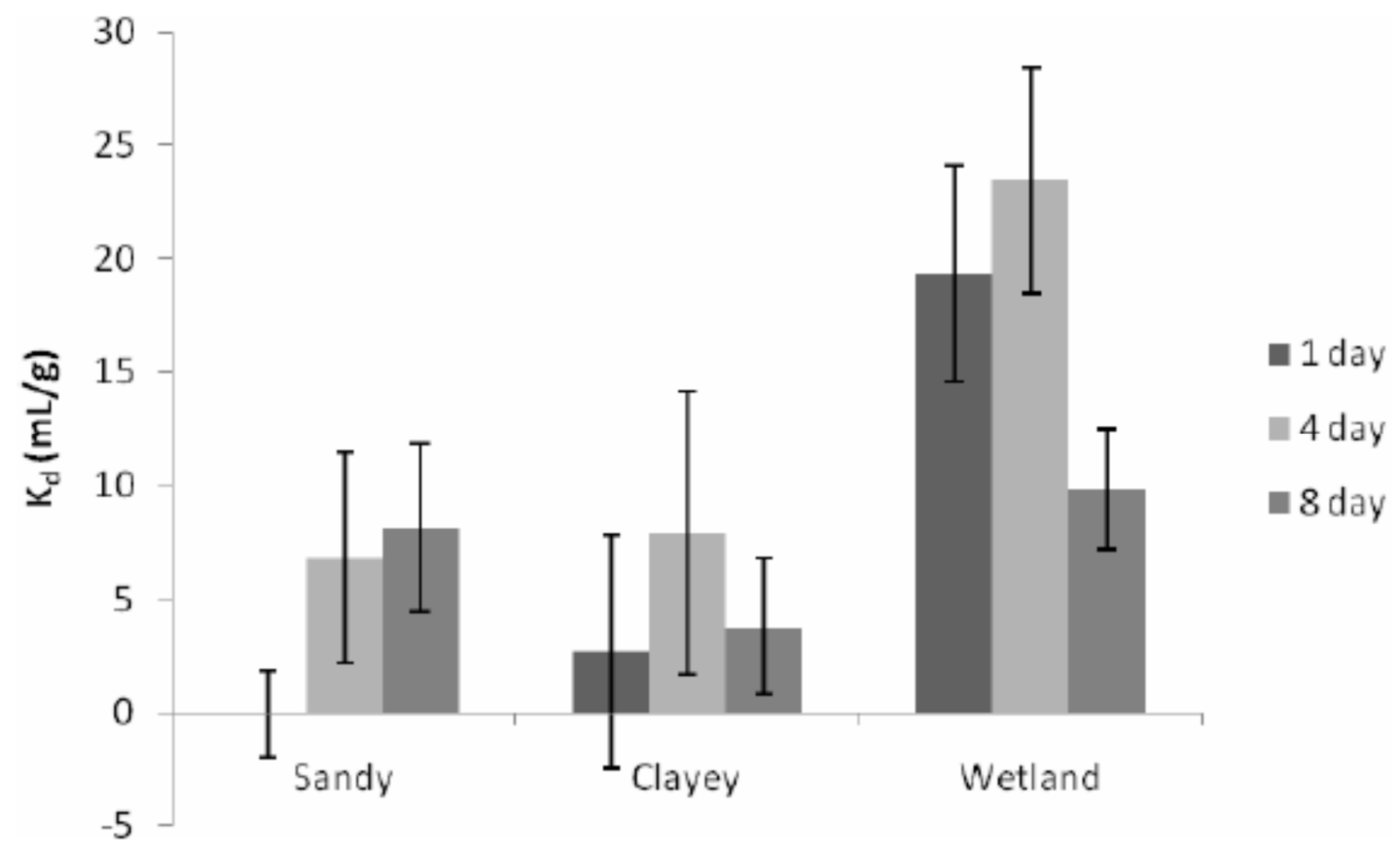

Figure 12. Iodine added as iodide $K_{d}$ values of sediments under reducing conditions af ter 1,4 , and 8 day equilibration times. Average and standard deviation of $I_{i o d i d e} K_{d}$ values of 9 samples with varying amendment concentrations (except for the 1 and 4 day clayey, and 1 day wetland where $n=$ 8 samples, 1 day clayey where $n=7$ samples, and 4 and 8 day sandy, and 4 day wetland where $n=6$ samples).

Table 9. Iodine added as iodide $\left(I_{\text {iodide }}\right) K_{d}$ values of sediments in oxidizing and reducing conditions after 8 days of equilibration. $K_{d}$ values corrected for natural iodine desorbed from sediments (uncorrected $K_{d}$ values presented in Figure 11and Figure 12).

\begin{tabular}{ccc}
\hline Sediment & Oxidizing & Reducing \\
\hline Sandy & $5.93 \pm 3.44$ & $8.09 \pm 3.68$ \\
Clayey & $8.04 \pm 7.21$ & $3.78 \pm 3.00$ \\
Wetland & $72.5 \pm 23.4$ & $9.79 \pm 2.69$ \\
\hline
\end{tabular}

It is difficult to find studies using analogous sediments with which to compare this data. Kaplan et al. (2000) used sediments with the closest composition to the sandy sediment in this study, but their sorption experiments were at a $\mathrm{pH}$ slightly above 8 , whereas these $\mathrm{pH}$ values were around 5 . They observed $\mathrm{I}_{\text {iodide }}$ $\mathrm{K}_{\mathrm{d}}$ values of approximately $1-2 \mathrm{~mL} / \mathrm{g}$ after 7 days, which are lower than those reported here for the 8 day sandy sediment. This is likely due to the differences in $\mathrm{pH}$. At a $\mathrm{pH}$ of 5 there should be more positively charged binding sites for the anionic $\mathrm{I}^{-}$than at a $\mathrm{pH}$ of 8 . Although $\mathrm{K}_{\mathrm{d}}$ values were not calculated, Yamaguchi et al. (2006) monitored concentrations of extracted iodide over time. They noted retardation of the spiked iodide with some fraction iodide being more strongly associated with the sediments. This conclusion was based on the findings that $\mathrm{NO}_{3}{ }^{-}$was able to leach some iodide from the sediments, but a retreatment of $\mathrm{SO}_{4}{ }^{2-}$ was able to recover additional iodide.

Iodine Added as Iodate Sorption to Sediments under Oxidizing Conditions: $I_{\text {iodate }} K_{d}$ measurements were made that were experimentally comparable to the $\mathrm{I}_{\text {iodide }} \mathrm{K}_{\mathrm{d}}$ values presented in Figure 
11, Figure 12, and Table 9, except iodate and not iodide was amended to the systems (Figure 13). Under oxidizing conditions, iodate is expected to have a higher degree of sorption to sediments than its reduced form iodide (Fox et al., 2010). There was some sorption to the sandy sediment with a steady state $\mathrm{K}_{\mathrm{d}}$ value of around $5 \mathrm{~mL} / \mathrm{g}$. This was reached by the 1 day sampling event. This value is similar to that of $\mathrm{I}_{\text {iodide }} \mathrm{K}_{\mathrm{d}}$ value under oxidizing conditions (Figure 11). However, there was a noticeable increase in the clayey and wetland sediments' $I_{\text {iodate }} K_{d}$ values (Figure 13) compared to the $I_{\text {iodide }} K_{d}$ values. The clayey sediment $\mathrm{I}_{\text {iodate }} \mathrm{K}_{\mathrm{d}}$ value is just over $40 \mathrm{~mL} / \mathrm{g}$, and like the sandy sediment $\mathrm{I}_{\text {iodate }} \mathrm{K}_{\mathrm{d}}$ value, steady-state was quickly reached. As was the case when iodide was used, the wetland sediment showed the most sorption. However, even after 8 days, steady state had not been reached, suggesting either diffusion or additional chemical reactions continued to occur during the initial 8 days. At the 8 day event, the average $\mathrm{I}_{\text {iodate }} \mathrm{K}_{\mathrm{d}}$ value was about $80 \mathrm{~mL} / \mathrm{g}$.

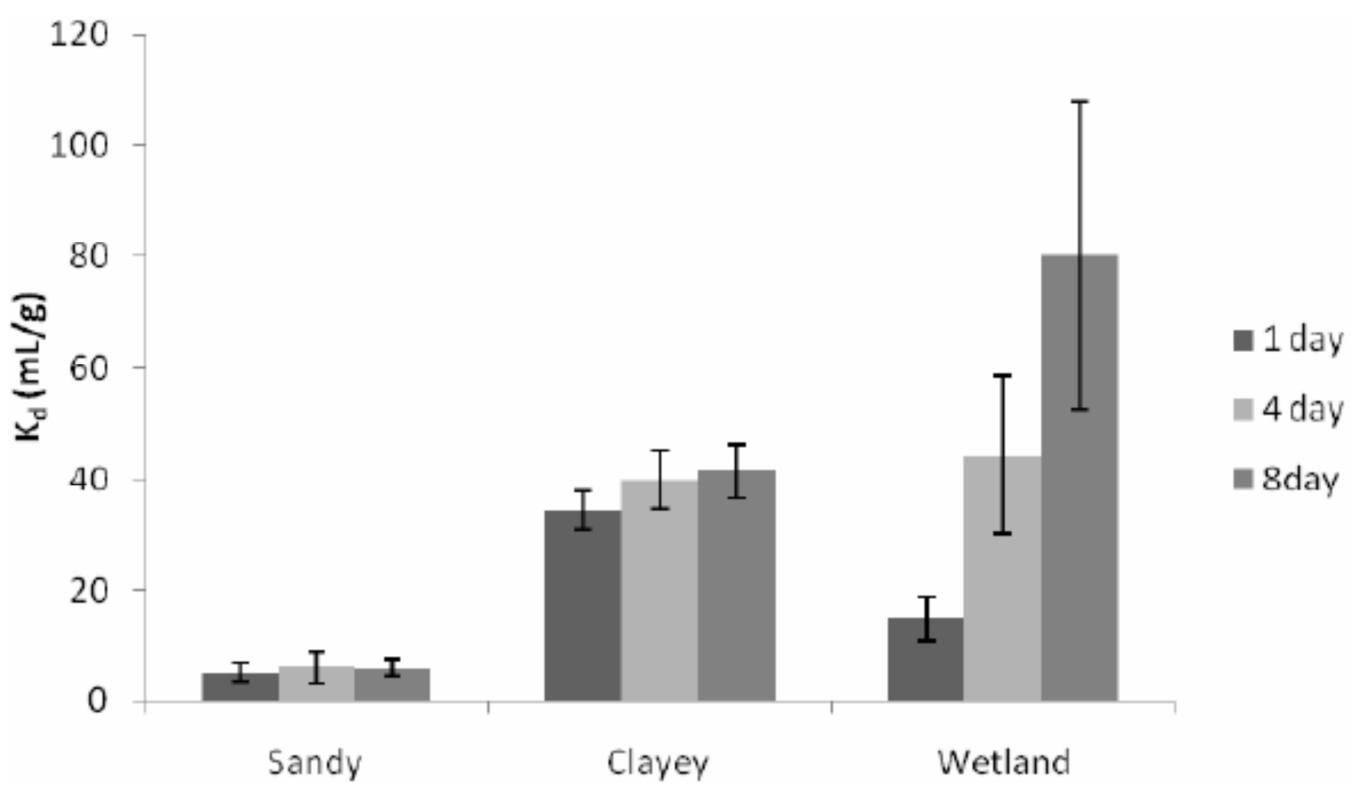

Figure 13. Iodine added as iodate $K_{d}$ values of sediments under oxidizing conditions. $\mathbf{I}_{\text {iodate }} \mathbf{K}_{\mathbf{d}}$ values measured after 1, 4, and 8 day equilibration times. Means and standard deviations of nine samples of varying concentrations (except for the following: sandy 4 and 8 day $n=8$ samples, clayey 1, 4, and 8 day and the wetland 1 and 4 day $n=6$ samples, and the wetland 4 day $n=5$ samples).

Although the standard deviations in Figure 13 are small for the sandy and clayey sediments, they are large for the wetland sediments. The data in Figure 13 is presented as fraction of the initial iodine remaining in the aqueous phase in Table 10. This shows that the large standard deviation in the wetland sediment $\mathrm{K}_{\mathrm{d}}$ value actually represents only about an $11 \%$ standard deviation in the fraction of the initial iodine remaining in the aqueous phase. Also the relatively small change in the aqueous fractions for the sandy and clayey sediments from the 1 and 8 day sampling events is further evidence that equilibrium is reached by the 1 day mark. However, there is a significant and steady decrease in the aqueous fraction in the wetland sediment from the 1 to 8 day events, which suggests equilibrium has not been reached by the 4 day sampling event. 
SRNL-STI-2012-00518

Revision 0

Table 10. Aqueous fraction $\left(\mathrm{I}_{\mathrm{aq}} / \mathrm{I}_{\text {total }}\right)$ of iodine (added as iodate) for sediments under oxidizing conditions.

\begin{tabular}{cccc}
\hline Sediment & 1 Day & 4 Day & 8 Day \\
\hline Sandy & $0.891 \pm 0.033$ & $0.872 \pm 0.051^{*}$ & $0.872 \pm 0.032^{*}$ \\
Clayey & $0.540 \pm 0.025^{* *}$ & $0.503 \pm 0.034^{* *}$ & $0.494 \pm 0.029^{* *}$ \\
Wetland & $0.707 \pm 0.098^{* *}$ & $0.496 \pm 0.078^{* * *}$ & $0.326 \pm 0.113^{* *}$ \\
\hline
\end{tabular}

Means and standard deviations of 9 samples

$* \mathrm{n}=8$ samples for the mean and standard deviation

$* * \mathrm{n}=6$ samples for the mean and standard deviation

$* * * \mathrm{n}=5$ samples for the mean and standard deviation

Iodine Added as Iodate Sorption to Sediments under Reducing Conditions: $I_{\text {iodate }}$ sorption to the clayey and wetland sediments (sandy sediments not included in these tests) was also examined under reducing conditions using an anaerobic glove box $\left(98 \% \mathrm{~N}_{2}(g)\right.$ and $2 \% \mathrm{H}_{2}(\mathrm{~g})$ atmosphere). The resulting average $\mathrm{K}_{\mathrm{d}}$ values are plotted in Figure 14. For the clayey sediment, there are small, albeit statistically insignificant, increases from day 1 to day 8 . Therefore, steady state appears to be reached by the day 1 sampling event. The resulting $\mathrm{K}_{\mathrm{d}}$ values agree with those measured under oxidizing conditions (Figure 13), suggesting iodate is not being reduced to the weaker sorbing iodide species within 8 days. If iodate was being reduced to iodide, the resulting $K_{d}$ values would be more similar to the $I_{\text {iodide }} K_{d}$ values under reducing conditions. As for the wetland sediment $\mathrm{K}_{\mathrm{d}}$ values, there was significant sorption after 1 day of contact, followed by a significant decrease in sorption at 4 and 8 days. This suggests the iodate in the wetland sediment suspension was being reduced to iodide by day 4. It appears equilibrium was reached after 4 days, and the resulting average $\mathrm{K}_{d}$ value at day 8 was in agreement with the equilibrium $\mathrm{I}_{\text {iodide }} \mathrm{K}_{\mathrm{d}}$ value and the wetland sediment under reducing conditions seen in Figure 12, further supporting the idea that iodate had undergone reduction to iodide during the study. 


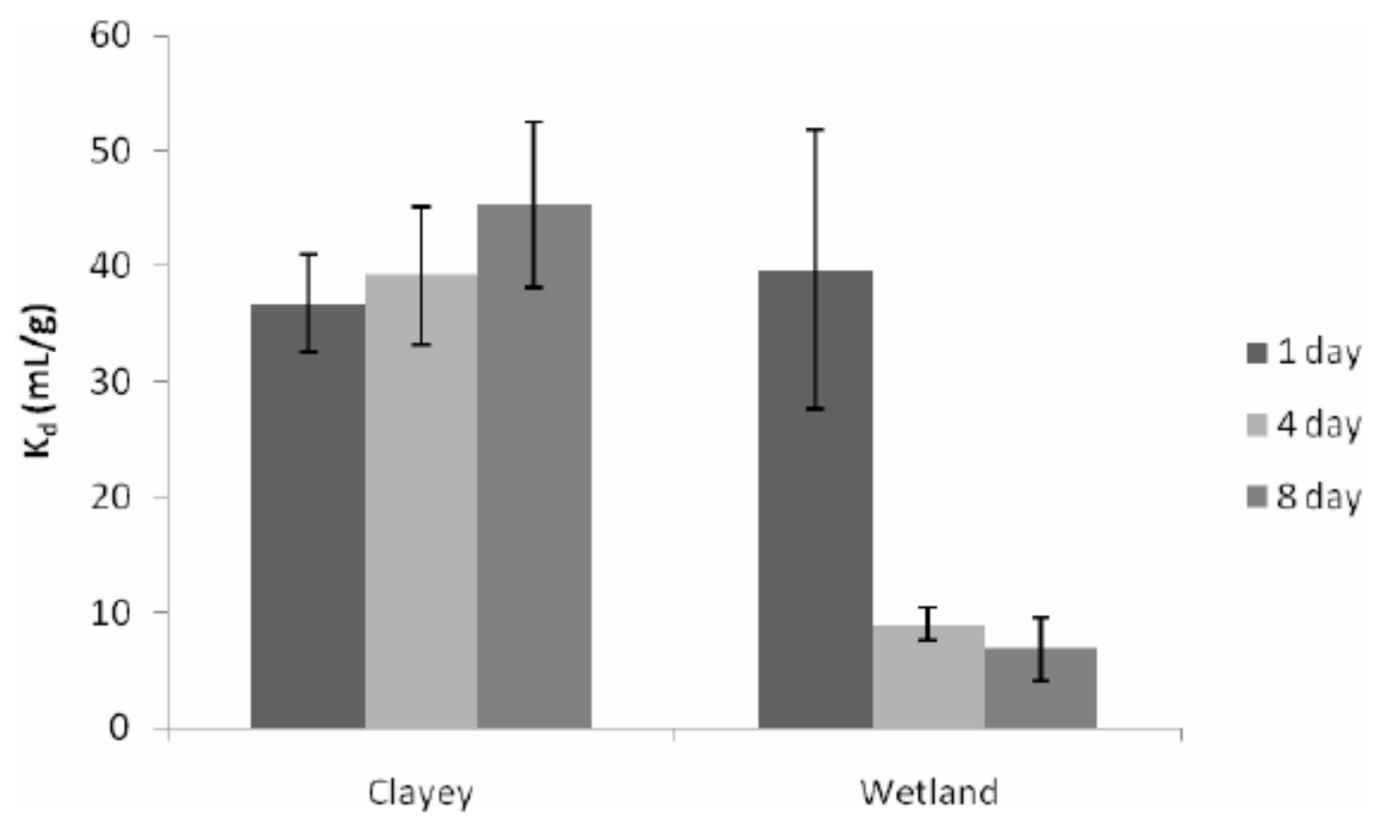

Figure 14. Iodine added as iodate $K_{d}$ values for sediments under reducing conditions. $I_{\text {iodate }} K_{d}$ values measured after 1,4 , and 8 days of contact. The means and standard deviations represent the averages of six samples (except for the wetland 4 and 8 day samples, where $n=5$ samples).

As was the case with many of the iodine experiments, the standard deviations associated with the $\mathrm{K}_{\mathrm{d}}$ values of iodate under reducing conditions are large. The aqueous fractions better represent the agreement of the samples and are found below in Table 61. In the case of the clayey sediment, there is a decrease of $5 \%$ in the iodine fraction from day 1 to day 8 , suggesting equilibrium is reached around day 1 . However, for the wetland sediment, there is an increase in the fraction of aqueous iodine of $35 \%$ from day 1 to day 8 . This suggests the iodate was being reduced to iodide causing it to desorb. This increase is most significant from day 1 to day 4 . From day 4 to day 8 there is an increase of $<5 \%$ indicating it may have reached steady state. It is also important to note that the largest standard de viation of $8.4 \%$ is associated with the wetland sediment at 1 day, while all other standard deviations were $<5 \%$.

Table 61. Aqueous fraction $\left(I_{a q} / I_{\text {total }}\right)$ of iodine (added as iodate) for sediments under reducing conditions.

\begin{tabular}{cccc}
\hline Sediment & 1 Day & 4 Day & 8 Day \\
\hline Clayey & $0.526 \pm 0.031$ & $0.511 \pm 0.0400$ & $0.476 \pm 0.0420$ \\
Wetland & $0.513 \pm 0.084$ & $0.825 \pm 0.0230^{*}$ & $0.862 \pm 0.0480^{*}$ \\
\hline
\end{tabular}

Averages and standard deviations of six samples

$*_{n}=5$ for the data set

The $\mathrm{I}_{\text {iodate }}$ 8-day $\mathrm{K}_{\mathrm{d}}$ values for the clayey and wetland sediments under both oxidizing and reducing conditions are shown below in Table. There is no discernible difference between the two sets of clayey 
data. However this is not the case for the wetland sediment. These data indicate that the relatively high $\mathrm{K}_{\mathrm{d}}$ values observed for the wetland sediment under oxidizing conditions may not persist under reducing conditions. This finding has large implications regarding development of conceptual models of iodine biogeochemical behavior.

Table 7. Iodine added as iodate $\left(\mathrm{I}_{\text {iodate }}\right) \mathrm{K}_{\mathrm{d}}$ values of sediments in oxidizing and reducing conditions after 8 days of equilibration (data used here is presented in more detail in Figure 13 and Figure 14).

\begin{tabular}{lcc}
\hline Sediment & Oxidizing & Reducing \\
\hline Clayey & $41.4 \pm 4.99$ & $45.3 \pm 7.19$ \\
& $(\mathrm{n}=6)$ & $(\mathrm{n}=6)$ \\
Wetland & $80.3 \pm 27.7$ & $6.82 \pm 2.72$ \\
& $(\mathrm{n}=5)$ & $(\mathrm{n}=5)$ \\
\hline
\end{tabular}

\subsection{Implications of these results for SRS performance assessments}

- Iodide and especially iodate sorption to subsurface sediments is very sensitive to system $\mathrm{pH}$ levels, decreasing $\mathrm{K}_{\mathrm{d}}$ with increasing $\mathrm{pH}$ values.

- Samples prepared with initially iodate and iodide had similar $\mathrm{K}_{\mathrm{d}}$ values under reducing and oxidizing conditions on the clayey and sandy sediments.

- $\mathrm{K}_{\mathrm{d}}$ values for initially iodate and initially iodide systems in wetland sediment suspensions were lower under reducing conditions (relative to oxidizing conditions).

- Iodate $\mathrm{K}_{\mathrm{d}}$ trends tended to resemble in trend and magnitude those of iodide, as contact time with sediment increased. This suggested that the iodate may have been converting to iodide.

\subsection{Conclusions}

${ }^{129}$ I exists in SRS groundwater as iodide, iodate, and organo iodine. Based on the background wells in F-Area that were minimally impacted by the adjacent acidic contaminant plume, Otosaka et al. (2011) reported that approximately $15 \%$ of the groundwater ${ }^{127}$ I was iodide, $42 \%$ was iodate, and the remaining $43 \%$ was organo-iodide (Table 8 ). This is our best estimate to date of what ${ }^{129}$ I speciation would be in a far-field ${ }^{129}$ I plume emanating from the Low-Level Waste Disposal Facility. The net effect of these multiple speciation is that the pool of ${ }^{129} \mathrm{I}$ would have a greater $\mathrm{K}_{\mathrm{d}}$ value than if the ${ }^{129} \mathrm{I}$ was composed entirely of iodide, as was previous assumed in iodine $\mathrm{K}_{\mathrm{d}}$ measurements of SRS sediments.

Table 83. Percent iodine species in groundwater that was minimally impacted by the presence of the F-Area plume (Table 2).

\begin{tabular}{lccccccc}
\hline Well & $\begin{array}{c}\text { iodide } \\
(\mathbf{n M} / \mathbf{L})\end{array}$ & $\begin{array}{c}\text { iodate } \\
(\mathbf{n M} / \mathbf{L})\end{array}$ & $\begin{array}{c}\text { organo-I } \\
(\mathbf{n M} / \mathbf{L})\end{array}$ & $\begin{array}{c}\text { Total I } \\
(\mathbf{n M} / \mathbf{L})\end{array}$ & $\begin{array}{c}\text { iodide } \\
(\mathbf{\%})\end{array}$ & $\begin{array}{c}\text { iodate } \\
(\%)\end{array}$ & $\begin{array}{c}\text { organo-I } \\
(\mathbf{\%})\end{array}$ \\
\hline FSB-109D & 3 & 4.6 & 35.5 & 43.1 & $7 \%$ & $11 \%$ & $82 \%$ \\
FSB-118D & 3.7 & 27 & 2.7 & 33.4 & $11 \%$ & $81 \%$ & $8 \%$ \\
FSB-120D & 16.2 & 21.7 & 25 & 62.9 & $26 \%$ & $34 \%$ & $40 \%$ \\
Average & & & & & $15 \%$ & $42 \%$ & $43 \%$ \\
\hline
\end{tabular}


When iodide was added to a sandy subsurface sediment (low organic matter concentrations) under oxidized conditions, the aqueous speciation did not change greatly and about $20 \%$ of the total iodine was taken up by the sediment (Xu et al. 2011a). When iodate was added to the same sediment, about $20 \%$ immediately converted to iodide, and about $40 \%$ of the total iodine partitioned to the sediment. This resulted in greater $I_{\text {iodate }} K_{d}$ values $(5.16 \mathrm{~mL} / \mathrm{g})$ than $I_{\text {iodide }} K_{d}$ values $(0.71 \mathrm{~mL} / \mathrm{g})($ Table 4$)$. Emerson et al. (2012) measured similar $\mathrm{K}_{\mathrm{d}}$ values when iodide $(5.93 \pm 3.44 \mathrm{~mL} / \mathrm{g})$ or iodate $(8.09 \pm 3.68 \mathrm{~mL} / \mathrm{g})$ was added to similar (but not identical) subsurface sandy sediment (Table ). Iodine sorption was not always greater under oxidizing conditions (more inclined to form iodate) than reducing conditions (more inclined to form iodide). This difference was especially acute for the wetland sediment, but was less obvious for the low organic matter subsurface sediments (Table ).

In regard to kinetics and when steady state is achieved, there is an important distinction between these experimental conditions and those anticipated in the PA when an ${ }^{129}$ I groundwater plume moves through the subsurface environment. Under experimental conditions, iodide or iodate was spiked into the sediment suspension and iodine speciation transformations took place prior to and after sorption, thereby delaying achieving steady state. Under expected field conditions, the groundwater ${ }^{129}$ I will very rapidly (within a week or two) approach steady state, and then after would approach equilibrium (partitioning) with the sediment comparatively quickly $(<4$ days; Figure 3$)$.

Perhaps the single most important new observation with regard to the PA is that desorption $\mathrm{K}_{\mathrm{d}}$ values were appreciably greater than (ad)sorption $K_{d}$ values. For the subsurface sandy sediment, the iodide (ad)sorption $K_{d}$ was 0.71 and desorption $K_{d}$ value was $23.89 \mathrm{~mL} / \mathrm{g}$. Similarly, iodate (ad)sorption $\mathrm{K}_{\mathrm{d}}$ value was $5.16 \mathrm{~mL} / \mathrm{g}$ and the desorption $\mathrm{K}_{d}$ value was $9.75 \mathrm{~mL} / \mathrm{g}$ (Table 4). These results imply that desorption processes would be appreciably slower than the (ad)sorption process, and as such would control the rate at which iodine sorbs to and moves through the subsurface sediment. This sorption hysteresis has been measured before on SRS and other sediments (reviewed in Kaplan et al. 2012; (Kaplan et al., 2000; Um et al., 2004). Higher desorption than (ad)sorption $\mathrm{K}_{\mathrm{d}}$ values would result in the "effective $K_{d}$ " for a reactive transport model being closer to desorption $K_{d}$ values (the rate limiting value) than (ad)sorption $\mathrm{K}_{\mathrm{d}}$ values.

There are no estimates, either using site-specific systems or more generally in the literature, on organo-iodine $K_{d}$ values. The paucity of data exists because there are several different forms of organic matter that exists in nature, and they would be expected to differ in the manner in which they interacted with sediment surfaces.

Based on these new experimental results, new best estimates are proposed for future PA calculations (Table 9). These changes are proposed primarily because: 1) not only iodide, but also the more strongly sorbing iodate species exists in SRS groundwater, 2) when iodine was added as iodate, the measured $\mathrm{K}_{\mathrm{d}}$ values were 3 to 6 times greater than when the iodine was added as iodide, and perhaps most importantly 3) higher desorption (10 to $20 \mathrm{~mL} / \mathrm{g}$ ) than (ad)sorption (as previously measured) $\mathrm{K}_{d}$ values were measured. There are no single experimental values that capture the single "best" $\mathrm{K}_{\mathrm{d}}$ estimates. Had systems come to steady state with respect to iodine chemistry, than we would obtain the same iodine $\mathrm{K}_{\mathrm{d}}$ values irrespective of whether iodide or iodate was added. This was most closely approximately by the data in Table, where the two subsurface inorganic sediments had similar iodide and iodate $\mathrm{K}_{\mathrm{d}}$ values, but the values for the organic wetland sediment varied greatly. Results from experiments reporting negative $\mathrm{K}_{\mathrm{d}}$ estimates (Figure 8 and Figure 7) were not weighed heavily because it was clear, as discussed in Section 3.2, that natural iodine had desorbed from the sediment and this pool of iodine was not accounted for in the $\mathrm{K}_{\mathrm{d}}$ calculations (however the trends and relative changes in iodine $K_{d}$ are very valuable for understanding ${ }^{129} \mathrm{I}$ geochemistry). Taking the above observations into consideration, yet erring on the side of selecting low 
SRNL-STI-2012-00518

Revision 0

$K_{d}$ values to underestimate ${ }^{129}$ I retention by the subsurface sediment, it is recommended that the new $K_{d}$ value be increase as shown in Table 9.

Table 9. Previous (Kaplan 2009) and proposed best-estimate sediment iodine $K_{d}$ values for SRS PA calculations.

\begin{tabular}{|c|c|c|}
\hline Subsurface sediment type & Previous $K_{d}(m L / g ;$ Kaplan 2009) & Proposed new $K_{d}$ values $(\mathrm{mL} / \mathrm{g})$ \\
\hline Sandy & 0.3 & 1 \\
\hline Clayey & 0.9 & 3 \\
\hline
\end{tabular}




\subsection{References}

Baas-Becking, L. G. M., Kaplan, I. R., and Moore, D. (1960). Limits of the natural environment in terms of $\mathrm{pH}$ and oxidation-reduction potentials. Journal of Geology $6 \mathbf{8 .}$

Denham, M. E., Kaplan, D. I., and Yeager, C. M. (2009). "Groundwater radioiodine: prevalence, biogeochemistry, and potential remedial approaches." Savannah River National Laboratory, Aiken, SC.

DOE (2002). "Yucca Mountain site suitability evaluation " Rep. No. DOE/RW-0549, U.S. Department of Energy - Office of Civilian Radioactive Waste Management.

DOE (2003). "Preliminary Performance Assessment for Waste Management Area C at the Hanford Site," Rep. No. DOE/ORP-2003-11, Department of Energy, Richland Operations Office, Richland, WA.

DOE (2012). "Proposed plan for remediation of the 200-UP-1 groundwater operable unit," Rep. No. DOE/RL-2010-05, Rev. 0, Deaprtment of Energy, Richland Operations Office, Richland, WA.

Emerson, H. P., and Powell, B. A. (2012). "Examination of geochemical controls of iodine transport in SRS subsurface environments," Rep. No. SC0250, Clemson University, Anderson, SC.

Kantelo, M. V., Bauer, L. R., Marter, W. L., Murphy, C. E., Jr., and Zeigler, C. C. (1990). "Radioiodine in the Savannah River Site Environment," Rep. No. WSRC-RP-90-424-2, Westinghouse Savannah River Company, Aiken, SC.

Kaplan, D. I. (2002). Influence of surface charge of an Fe-oxide and an organic matter dominated soil on iodide and pertechnetate sorption. Radiochim Acta 91, 173-178.

Kaplan, D. I. (2009). "Geochemical Data Package for Performance Assessment Calculations Related to the Savannah River Site," Rep. No. SRNL-STI-2009-00473, Savannah River National Laboratory, Aiken, SC.

Kaplan, D. I., Mattigod, S., Parker, K. E., and Iversen., G. (2000). " I-129 Test and Research to Support Disposal Decisions," Rep. No. WSRC-TR-2000-00283, Rev. 0, Westinghouse Savannah River Company, Aiken, SC.

Kaplan, D. I., Roberts, K. A., Schwehr, K. A., Lilley, M. S., Brinkmeyer, R., Denham, M. E., Diprete, D., Li, H. P., Powell, B. A., Xu, C., Yeager, C. M., Zhang, S. J., and Santschi, P. H. (2011). Evaluation of a radioiodine plume increasing in concentration at the Savannah River Site. Environmental Science \& Technology 45, 489-495.

Kaplan, D. I., Serkiz, S. M. (2006). "Influence of Dissolved Organic Carbon and pH on Iodide, Perrhenate, and Selenate Sorption to Sediment," Rep. No. WSRC-STI-2006-00037, Washington Savannah River Company, Aiken, SC.

Kaplan, D. I., and Serne, R. J. (1998). Pertechnetate exclusion from sediments. Radiochimica Acta 81, 117-124.

Kaplan, D. I., Yeager, C., Denham, M. E., Zhang, S., Xu, C., Schwehr, K. A., Li, H.-P., Ho, Y.-F., Brinkmeyer, R., and Santschi, P. H. (2012). "Biogeochemical considerations related to the remediation of ${ }^{129}$ I plumes," Rep. No. SRNL-STI-2012-00425, Savannah River National Laboratory, Aiken, SC.

Killian, T. H., Kolb, N. L., Corbo, P., and Marine, I. W. (1985). "F-Area Seepage Basins," Rep. No. SPST-85-704, E. I. du Pont de Nemours \& Co., Savannah River Laboratory, Aiken, $\mathrm{SC}$.

Lilley, M. S., Powell, B. A., and Kaplan, D. I. (2010). Sorption of Np, Pu, Tc, and I to saltstone and cement formulations under oxidizing and reducing conditions. Geochimica et Cosmochimica Acta 74, A605-A605. 
Millings, M. R., Nookester, J. V., Denham, M. E., and Jackson, B. P. (2003). "Natural strontium, iodine, cesium, and cobalt in Savannah River Site groundwater: Data report." WSRC-TR2002-00479. Aiken, SC, Savannah River National Laboratory.

Otosaka, S., Schwehr, K. A., Kaplan, D. I., Roberts, D. A., Zhang, S., Xu, C., Li, H.-P., Ho, Y.-F., Brinkmeyer, R., Yeager, C. M., and Santschi, P. H. (2011). Transformation and transport processes of ${ }^{127} \mathrm{I}$ and ${ }^{129} \mathrm{I}$ species in an acidic groundwater plume at the Savannah River Site. The Science of the Total Environment 409, 3857-3865.

Santschi, P. H., Xu, C., Zhang, S., Ho, Y. F., Li, H.-P., Schwehr, K. A., and Kaplan, D. I. (2012). "Laboratory report on iodine (129I and 127I) speciation, transformation and mobility in Hanford groundwater, suspended particles and sediments ", SRNL-STI-2012-00592. Savannah River National Laboratory, Aiken, SC.

Schwehr, K. A., and Santschi, P. H. (2003). Sensitive determination of iodine species, including organo-iodine, for freshwater and seawater samples using high performance liquid chromatography and spectrophotometric detection. Analytica Chimica Acta 482, 59-71.

Schwehr, K. A., Santschi, P. H., Kaplan, D. I., Yeager, C. M., and Brinkmeyer, R. (2009). Organo-iodine formation in soils and aquifer sediments at ambient concentrations. Environmental Science \& Technology 43, 7258-7264.

Stone, J. A., Oblath, S. B., Hawkins, R. H., Grant, M. W., Hoeffner, S. L., and King., C. M. (1985). "Waste migration studies at the Savannah River Plant Burial Ground," Rep. No. DP-MS-85-86, E. I. Dupont de Nemours \& Co., Aiken, SC.

Um, W., Serne, R. J., and Krupka, K. M. (2004). Linearity and reversibility of iodide adsorption on sediments from Hanford, Washington under water saturated conditions. Water Research 38, 2009-2016.

WSRC (2006). "Annual Corrective Action Report for the F-Area Hazardous Waste Management Facility, the H-Area Hazardous Waste Management Facility, and the Mixed Waste Management Facility," Rep. No. WSRC-RP-2006-4011, Westinghouse Savannah River Company, LLC, Aiken, SC.

WSRC (2008). " E-Area Low-Level Waste Facility DOE 435.1 Performance Assessment," Rep. No. WSRC-STI-2007-00306, REVISION 0, Washington Savannah River Company, Aiken, SC.

Xu, C., Miller, E. J., Zhang, S., Li, H. P., Ho, Y. F., Schwehr, K. A., Kaplan, D. I., Otosaka, S., Roberts, K. A., Brinkmeyer, R., Yeager, C. M., and Santschi, P. H. (2011a). Sequestration and remobilization of radioiodine (I-129) by soil organic matter and possible consequences of the remedial action at Savannah River Site. Environmental Science \& Technology 45, 9975-9983.

Xu, C., Zhang, S., Ho, Y.-F., Miller, E. J., Roberts, K. A., Li, H.-P., Schwehr, K. A., Otosaka, S., Kaplan, D. I., Brinkmeyer, R., Yeager, C. M., and Santschi, P. H. (2011b). Is soil natural organic matter a sink or source for mobile radioiodine $\left({ }^{129} \mathrm{I}\right)$ at the Savannah River Site? Geochimica et Cosmochimica Acta 75, 5716-5735.

Xu, C., Zhang, S. J., Chuang, C. Y., Miller, E. J., Schwehr, K. A., and Santschi, P. H. (2011c). Chemical composition and relative hydrophobicity of microbial exopolymeric substances (EPS) isolated by anion exchange chromatography and their actinide-binding affinities. Marine Chemistry 126, 27-36.

Xu, C., Zhong, J. Y., Hatcher, P. G., Zhang, S., Li, H. P., Ho, Y., Schwehr, K. A., Kaplan, D. I., Roberts, K. A., Brinkmeyer, R., Yeager, C. M., and Santschi, P. H. (2012). Molecular environment of stable iodine and radioiodine $\left({ }^{129} \mathrm{I}\right)$ in natural organic matter: Evidence inferred from NMR and binding experiments at environmentally relevant concentrations. Geochimica et Cosmochimica Acta 97, 166-182.

Zhang, S., Du, J., Xu, C., Schwehr, K. A., Ho, Y., Santschi, P. H., and Kaplan, D. I. (2010a). Mobility of iodine ${ }^{(29}$ I and ${ }^{127}$ I) species in sediment columns from the Savannah River Site. Geochimica et Cosmochimica Acta 74, A1211-A1211. 
Zhang, S., Du, J., Xu, C., Schwehr, K. A., Ho, Y. F., Li, H. P., Roberts, K. A., Kaplan, D. I., Brinkmeyer, R., Yeager, C. M., Chang, H. S., and Santschi, P. H. (2011). ConcentrationDependent Mobility, Retardation, and Speciation of Iodine in Surface Sediment from the Savannah River Site. Environmental Science \& Technology 45, 5543-5549.

Zhang, S., Schwehr, K. A., Ho, Y. F., Xu, C., Roberts, K. A., Kaplan, D. I., Brinkmeyer, R., Yeager, C. M., and Santschi, P. H. (2010b). A novel approach for the simultaneous determination of iodide, iodate and organo-Iodide for ${ }^{127} \mathrm{I}$ and ${ }^{129} \mathrm{I}$ in environmental samples using Gas Chromatography-Mass Spectrometry. Environmental Science \& Technology 44, 9042-9048. 
SRNL-STI- 2012-00518

Revision 0

Appendix A: Additional Iodine $K_{d}$ Values for Wetland Sediments (Emerson et al. 2012) 
Iodine added as iodide sorption to the wetland sediment is presented in Figure 15. Similarly, iodine added as iodate $\left(\mathrm{I}_{\text {iodate }}\right)$ sorption to the wetland sediment is presented in Figure 16

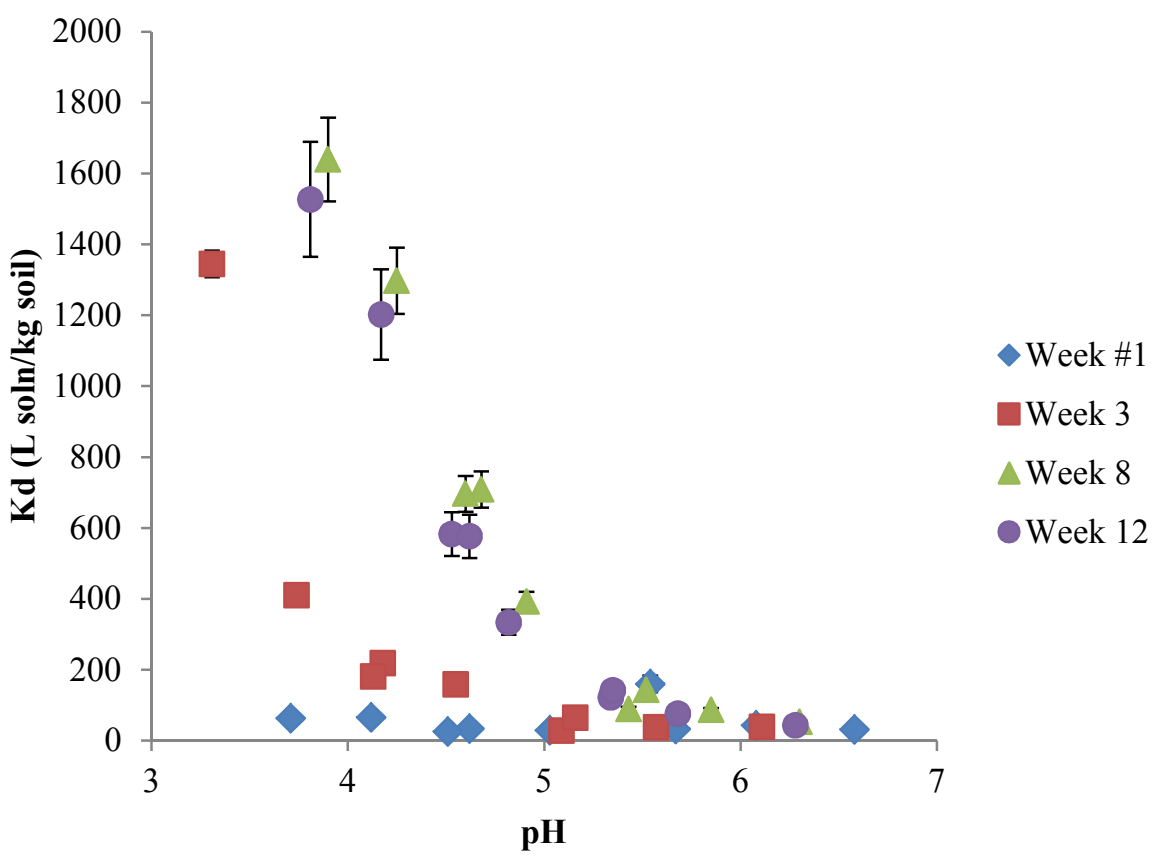

Figure 15. Iodine added as iodide $\left(\mathrm{I}_{\text {iodide }}\right)$ sorption wetland sediment suspensions as a function of $\mathrm{pH}\left(25 \mathrm{~g} / \mathrm{L}\right.$ sediment; $\mathrm{I}_{\text {total }}=1000 \mathrm{ppb}$, and $0.01 \mathrm{M} \mathrm{NaCl}$ under aerobic conditions). 
SRNL-STI- 2012-00518

Revision 0

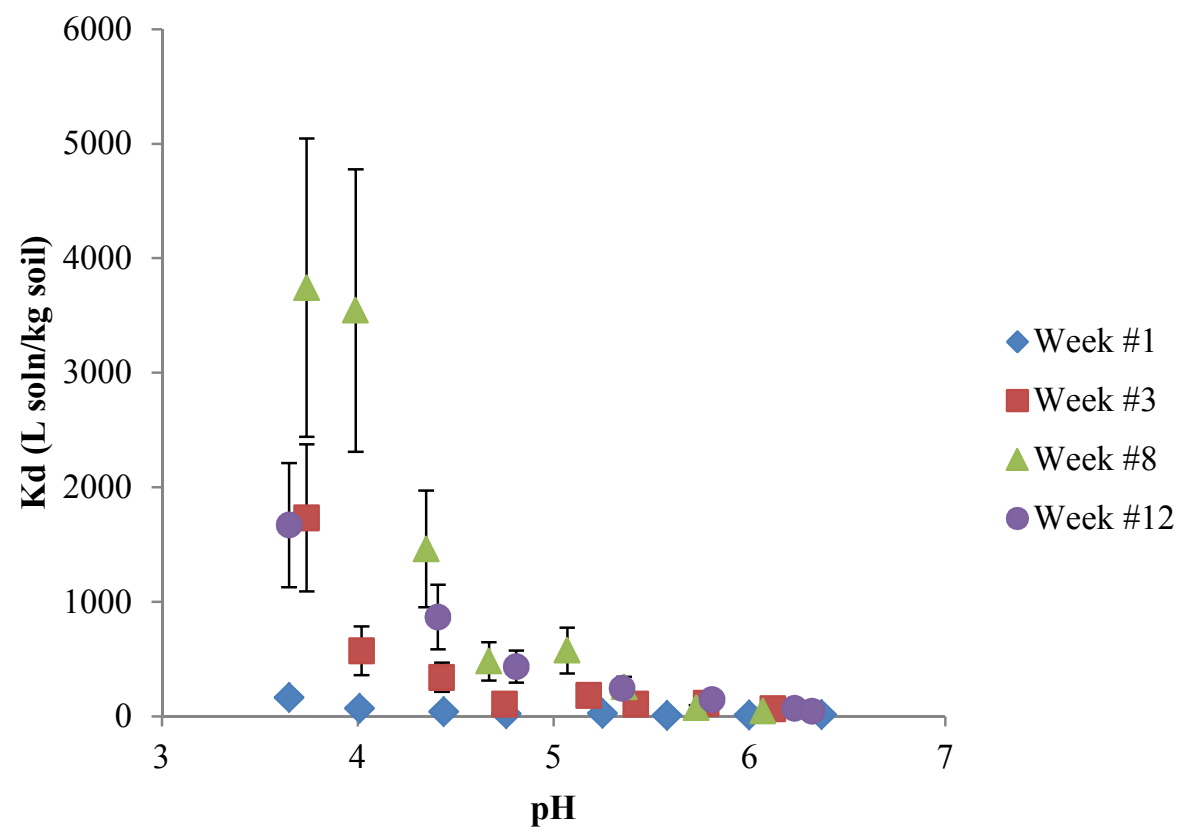

Figure 16. Iodine added as iodate $\left(\mathrm{I}_{\text {iodate }}\right)$ sorption to wetland sediment suspensions as a function of $\mathrm{pH}\left(25 \mathrm{~g} / \mathrm{L}\right.$ sediment; $\mathrm{I}_{\text {tota }}=1000 \mathrm{ppb}$; and $0.01 \mathrm{M} \mathrm{NaCl}$ under aerobic conditions). 


\section{Distribution:}

Savannah River Site

R. S. Aylward 773-42A, Rm. 281

B. T. Butcher 773-43A, Rm. 211

D. A. Crowley 773-43A, Rm. 216

J. C. Griffin 773A, Rm. A-231

D. I. Kaplan 773-43A, Rm. 215

J. J. Mayer 773-42A, Rm. 242

A. M. Murray 773A, Rm. A-229

K. A. Roberts 773-43A, Rm. 225

K. H. Rosenberger 705-1C, Rm. 16

RPA File ( 2 copies) 773-43A, Rm. 213

Clemson University, Department of Environmental and Earth Sciences and Earth, Computer Court, Anderson, SC 29625

H. P. Emerson

B. A. Powell

Texas A\&M University, Ocean and Coastal Studies Building, 200 Seawolf Parkway, Galveston, TX 77553

H. P. Li

P. H. Santschi

K. A. Schwehr

C. $\mathrm{Xu}$

S. Zhang 